\title{
Safety and efficacy of peramivir for influenza treatment
}

This article was published in the following Dove Press journal:

Drug Design, Development and Therapy

24 October 2014

Number of times this article has been viewed

\author{
Atsuko Hata ${ }^{1,2}$ \\ Ryoko Akashi-Ueda' \\ Kazufumi Takamatsu ${ }^{3}$ \\ Takuro Matsumura ${ }^{2}$ \\ 'Department of Pediatrics, \\ ${ }^{2}$ Department of Infectious Diseases, \\ ${ }^{3}$ Respiratory Disease Center, Division \\ of Respiratory Medicine, Kitano \\ Hospital, The Tazuke Kofukai Medical \\ Research Institute, Osaka, Japan
}

Objective: This report presents a review of the efficacy and safety of peramivir, a neuraminidase inhibitor that was granted Emergency Use Authorization by the US Food and Drug Administration (FDA) from October 23, 2009 to June 23, 2010 during the 2009 H1N1 pandemic.

Methods: Literature was accessed via PubMed (January 2000-April 2014) using several search terms: peramivir; BCX-1812; RWJ 270201; H1N1, influenza; antivirals; and neuraminidase inhibitors. The peramivir manufacturers, Shionogi and Co Ltd and BioCryst Pharmaceuticals, were contacted to obtain unpublished data and information presented at recent scientific meetings. Information was obtained from the Centers for Disease Control and Prevention (CDC) and from US FDA websites. English-language and Japanese-language reports in the literature were reviewed and selected based on relevance, along with information from the CDC, US FDA, and the drug manufacturers.

Results: We obtained eleven clinical trial reports of intravenous peramivir, two of which described comparisons with oseltamivir. Seven of nine other recently reported published studies was a dose-response study. Clinical reports of critically ill patients and pediatric patients infected with pandemic H1N1 described that early treatment significantly decreased mortality. Peramivir administered at $300 \mathrm{mg}$ once daily in adult patients with influenza significantly reduces the time to alleviation of symptoms or fever compared to placebo. It is likely to be as effective as other neuraminidase inhibitors.

Conclusion: Although peramivir shows efficacy for the treatment of seasonal and pH1N1 influenza, it has not received US FDA approval. Peramivir is used safely and efficiently in hospitalized adult and pediatric patients with suspected or laboratory-confirmed influenza. Peramivir might be a beneficial alternative antiviral treatment for many patients, including those unable to receive inhaled or oral neuraminidase inhibitors, or those requiring nonintravenous drug delivery.

Keywords: neuraminidase inhibitor, pandemic, pH1N1, avian flu, antiviral therapy, drug resistance

\section{Introduction}

Influenza, an acute febrile respiratory illness, is caused by influenza A or B virus. It occurs in outbreaks each year, mainly during winter. Signs and symptoms of upper and/ or lower respiratory tract involvement are common. Two major classes of antivirals are licensed for the treatment and prevention of influenza: M2 inhibitors and neuraminidase inhibitors (NAIs). ${ }^{1,2}$ The latter prevent the destruction of sialic acid-bearing receptors that are recognized by influenza $\mathrm{A}$ and $\mathrm{B}$ virus hemagglutinins which, in turn, prevents the virus from being released from infected cells and from passing through respiratory secretions to initiate new cycles of replication. ${ }^{3,4}$ NAIs are active against both influenza $\mathrm{A}$ and $\mathrm{B}$, although adamantanes, which include amantadine and rimantadine, are 
active only against influenza A. ${ }^{4}$ The Advisory Committee on Immunization Practices does not recommend adamantanes for influenza treatment because of an increase in resistant isolates in the United States..$^{5,88}$

Peramivir, classified with oseltamivir and zanamivir among the NAIs, was developed by BioCryst Pharmaceuticals, Inc. (Birmingham, AL, USA) for the treatment of influenza infection. ${ }^{6,7}$ Peramivir has significantly stronger binding affinity to the NA enzyme than either oseltamivir or zanamivir. Moreover, peramivir inhibits influenza A and B viruses, including influenza virus strains that might be resistant to other NAIs.

Oseltamivir is orally administered. Zanamivir and laninamivir are inhaled. By contrast, peramivir is the first intravenously administered NAI. Oral or inhalant administration to young children is difficult with peramivir, thereby limiting its treatment benefits. However, the availability of an intravenously administered NAI is expected to be especially important for treating patients who cannot take or tolerate oral or inhaled anti-influenza agents, such as young infants.

Intravenous administration of zanamivir or peramivir provides rapid drug delivery at high levels. It might affect the host's endogenous NA. ${ }^{8}$ In March 2007, BioCryst Pharmaceuticals, Inc. and Shionogi \& Company Ltd (Osaka, Japan) entered an exclusive license agreement to develop and commercialize peramivir in Japan for the treatment of seasonal and potentially life-threatening human influenza. ${ }^{9}$

Peramivir was emergently released during the pandemic of 2009 (April 3, 2009-August 31, 2010). ${ }^{10}$ Phase III clinical trials in Japan, Taiwan, and South Korea have demonstrated that intravenously administered peramivir is not inferior to oral oseltamivir for the treatment of adult patients with seasonal influenza A or B. ${ }^{11}$ From January 2010, peramivir was licensed for use in adults. Since October 2010, it has also been available in Japan for children, including neonates, with influenza infection. ${ }^{10}$ It has therefore been used in advance of the rest of the world, becoming available immediately after Phase III clinical trials in Japan. Its use has demonstrated that intravenously administered peramivir is safe and clinically and virologically effective for children with $\mathrm{pH} 1 \mathrm{~N} 1$ infection. ${ }^{12}$ Adult patients were also administered peramivir, but the pediatric peramivir preparation was almost too late for pandemic patients. In August 2010, peramivir was approved by the Korean Food and Drug Administration (KFDA). ${ }^{13}$ Peramivir is available in Japan as Rapiacta ${ }^{\mathrm{TM}}$ (Shionogi \&
Company Ltd) and in South Korea as PeramiFlu ${ }^{\mathrm{TM}}$ (Green Cross Corporation). ${ }^{13}$

Zanamivir and oseltamivir, which were approved in 1999, have since become commonly used in the US. Intravenously administered peramivir was granted Emergency Use Authorization (EUA) by the US FDA for the treatment of influenza in selected patients in the US based on favorable results of a multinational clinical trial approved in $2010 .{ }^{14}$ This EUA was the first to be issued for an unapproved drug. The grant, however, expired on June 23, 2010, when the pandemic ended. ${ }^{14}$ Many otherwise healthy children and adults, as well as high-risk patients in Japan with influenza virus infection, are currently treated with four NAIs: oseltamivir; zanamivir; laninamivir; and peramivir. The clinical effectiveness of peramivir has not yet been evaluated sufficiently in patients with influenza. This review describes the status of the research and clinical trials of peramivir for the treatment of pH1N1 influenza and/ or seasonal influenza during the postpandemic of 2009, and explains its potential to support therapeutic strategies for influenza virus infection.

\section{Objective}

This review was undertaken to present information about the clinical efficacy and safety (including adverse events [AEs]) of peramivir for the treatment of naturally acquired influenza. Clinical reports presenting data from placebocontrolled randomized trials and single-group studies were reviewed, along with regulatory comments and reviews of the safety and efficacy of peramivir for influenza in patients of all ages. This evaluation assesses related issues for at-risk and otherwise healthy populations.

\section{Methods}

\section{Data sources and search strategy}

A literature search was conducted using PubMed (US National Library of Medicine, Bethesda, MD, USA) (January 2000-March 2014) and the Cochrane Database (The Cochrane Collaboration, Oxford, UK) (January 2000 March 2014) with the following search terms: peramivir; BCX-1812; RWJ 270201; influenza; H1N1; antivirals; and NAIs. The peramivir manufacturers (Shionogi \& Company Ltd and BioCryst Pharmaceuticals, Inc.) were contacted to solicit unpublished data and information presented at recent scientific meetings. Additional information was obtained from Clinicaltrials.gov, the Centers for Disease Control and Prevention (CDC), and FDA Websites. Literature review 
articles were searched using PubMed and were referenced for this review.

\section{Study selection and data extraction}

Available English-language and Japanese-language reports were selected and reviewed, as was information from the CDC, FDA, and the Ministry of Health, Labour, and Welfare (Tokyo, Japan). The requirements for EUA for peramivir were also consulted.

Only published reports of trials that examined the use of peramivir, or those which evaluated peramivir versus placebos or another NI (oseltamivir) for the treatment of seasonal or pH1N1 influenza in healthy adults, children, elderly people, or at-risk individuals were considered. No search was performed before 2000 because peramivir (RWJ-270201/BCX-1812) was first introduced as a novel NAI for influenza in 2000. Experimental and clinical studies conducted in animal models such as mouse, ferret, equine, and macaque with influenza infections were considered. Clinical studies published in languages other than English or Japanese were excluded.

\section{Results}

Table 1 shows that we obtained eleven clinical trial reports. Reports of nine studies of peramivir in dose-response or placebo-controlled studies were found in the Cochrane Database of Systematic Reviews. ${ }^{15}$ We collected these reports and combined them with others from the clinicaltrials.gov Website (http://www.clinicaltrials.gov/), irrespective of whether they had been published or not. Details are presented in Table 2. We divided the results into four eras depending on the time when the trials were initiated: prepandemic development; prepandemic; pandemic; and postpandemic 2009.

\section{Clinical efficacy}

\section{Prepandemic development}

Eleven reports of Phase I, Phase II, and Phase III clinical trials examining the clinical efficacy and safety of peramivir treatment for influenza patients have been published (Table 1). These trials were performed during the eras of prepandemic and pandemic 2009. Preclinical studies and murine pharmacodynamic studies demonstrated high selectivity and efficacy of peramivir against both influenza $\mathrm{A}$ and $\mathrm{B}$ strains. ${ }^{22}$ In Phase I clinical trials, oral peramivir dosages of $0.5-800 \mathrm{mg} / \mathrm{kg} /$ day once daily for 10 days were well tolerated. ${ }^{16,17,19}$ Once-daily administration of peramivir was supported based on analyses of pharmacodynamics and effectiveness, for which we measured the time necessary for viral clearance in Phase II studies. ${ }^{17}$ Hayden et $a{ }^{18}$ reported a Phase I study using peramivir in influenza virus-infected patients, but a full description of the trial is not available. Two double-blind, placebo-controlled trials were conducted to ascertain the appropriate dosage with several dose regimens in subjects who had been infected experimentally with influenza A/Texas/36/91 or B/Yamagata/16/88 viruses. In these studies, $400 \mathrm{mg}$ administered orally once daily significantly reduced nasal wash virus titer. A second study showed that an oral loading dosage of $400 \mathrm{mg}$ or $800 \mathrm{mg}$ and $800 \mathrm{mg}$ once daily was effective in reducing viral titer. ${ }^{19}$ Symptoms were not significant in either group. Peramivir of 400-800 $\mathrm{mg}$ appeared to be well tolerated by these patients. ${ }^{19}$ Barroso et al $^{20}$ conducted randomized, controlled dose-response trials for the treatment of experimental human influenza. For the trials, 288 healthy adults were inoculated with influenza A or B. Oral peramivir treatment with dosages of $400 \mathrm{mg}$ once daily for 5 days significantly reduced the viral titer of influenza A. Both $400 \mathrm{mg}$ and $800 \mathrm{mg}$ once daily for 5 days reduced the titer of influenza B, as defined by the area under the curve values. ${ }^{20}$ Clinical trials of orally administered peramivir were conducted first. ${ }^{22}$ Peramivir showed low oral bioavailability. Expecting effects in other drug delivery routes, trials were designed to ascertain whether intravenously or intramuscularly administered peramivir can reduce viral titer, and to assess the time to alleviate influenza symptoms. ${ }^{21}$ The drug was developed as an intravenously administered preparation. Other Phase I, Phase II, and Phase III trials are described elsewhere. ${ }^{19,22}$

\section{Prepandemic era}

Clinical studies of healthy adults

The safety and efficacy of peramivir treatment in patients with uncomplicated seasonal influenza virus infection were first evaluated in dose-response studies. A placebo-controlled, double-blind Phase II study ${ }^{23}$ demonstrated that, compared with placebo, a single intravenous dose of peramivir at either $300 \mathrm{mg}$ (hazard ratio: 0.681; adjusted $P=0.0092$ ) or $600 \mathrm{mg}$ (hazard ratio: 0.666; adjusted $P=0.0092)$ significantly reduced the duration of influenza symptoms for adult influenza outpatients, irrespective of the influenza virus subtype or the duration of symptoms before the study (Table 1). A randomized, double-blind Phase III study ${ }^{11}$ comparing single-dose intravenously administered peramivir with oral oseltamivir in uncomplicated patients with seasonal influenza was conducted in Japan, Taiwan, and 
Table I Summary of clinical trials of peramivir treatment in patients with influenza virus infection

\begin{tabular}{|c|c|c|c|c|c|}
\hline Trial & Cohort (age) & Type & Study design & $\begin{array}{l}\text { Number of } \\
\text { subjects }\end{array}$ & Primary outcome \\
\hline Phase I & Healthy adults & Seasonal flu $A$ and $B$ & $\begin{array}{l}\text { I mg/kg, } 2 \mathrm{mg} / \mathrm{kg}, 4 \mathrm{mg} / \mathrm{kg} \text {, } \\
\text { and } 8 \mathrm{mg} / \mathrm{kg} \text { BID or placebo } \\
\text { for } 10 \text { days. }\end{array}$ & 84 & $\begin{array}{l}\text { Pharmacokinetics and } \\
\text { safety. }\end{array}$ \\
\hline Phase I & $\begin{array}{l}\text { Elderly, } \geq 65 \text { years } \\
\text { of age }\end{array}$ & Seasonal flu $A$ and $B$ & $\begin{array}{l}\text { Intravenous peramivir on day I; } \\
\text { thereafter, two cohorts of eight } \\
\text { subjects each (six peramivir, two } \\
\text { placebo) received } 4 \mathrm{mg} / \mathrm{kg} \text { BID for } \\
\text { either } 5 \text { days or } 10 \text { days. Up to } \\
800 \mathrm{mg} / \mathrm{kg} / \text { day for } 10 \text { days. }\end{array}$ & 20 & $\begin{array}{l}\text { Safety and } \\
\text { pharmacokinetics. }\end{array}$ \\
\hline Phase I & $\begin{array}{l}\text { Hospitalized } \\
\text { with uncomplicated } \\
\text { influenza } \geq 19 \text { years } \\
\text { of age }\end{array}$ & Seasonal flu $A$ and $B$ & $\begin{array}{l}\text { A single-center, crossover, } \\
\text { uncontrolled, open-label study } \\
\text { after intramuscular and intravenous } \\
\text { administration of a single dose } \\
\text { of } 75 \mathrm{mg}, 150 \mathrm{mg} \text {, or } 300 \mathrm{mg} \text { of } \\
\text { peramivir. }\end{array}$ & 27 & $\begin{array}{l}\text { Concentrations in the } \\
\text { secretion of peramivir; } \\
\text { a similar reduction in } \\
\text { viral titers observed } \\
\text { after } 48 \text { hours. }\end{array}$ \\
\hline Phase II & $\begin{array}{l}\text { Adults with positive } \\
\text { influenza } A \text { or } B \\
\text { (by RIDT) }\end{array}$ & Seasonal flu $A$ and $B$ & $\begin{array}{l}\text { Randomized, double-blind, } \\
\text { placebo-controlled, multicenter } \\
\text { administration of a single dose } \\
\text { of } 150 \mathrm{mg} \text { or } 300 \mathrm{mg} \text { of peramivir } \\
\text { or placebo (as an intramuscular } \\
\text { single dose) within } 48 \text { hours of } \\
\text { symptom onset. }\end{array}$ & 344 & $\begin{array}{l}\text { Time to the alleviation } \\
\text { of symptoms. }\end{array}$ \\
\hline Phase II & $\begin{array}{l}\text { Adults with positive } \\
\text { influenza A or B } \\
\text { (by RIDT) with } \\
\text { symptom duration } \\
\leq 48 \text { hours }\end{array}$ & Seasonal flu $A$ and $B$ & $\begin{array}{l}\text { Randomized, double-blind, } \\
\text { placebo-controlled, multicenter } \\
\text { administration of a single dose } \\
\text { of } 600 \mathrm{mg} \text { of peramivir or placebo } \\
\text { as an intramuscular single dose. }\end{array}$ & 402 & $\begin{array}{l}\text { Time to the alleviation } \\
\text { of symptoms. }\end{array}$ \\
\hline Phase II & $\begin{array}{l}\text { Hospitalized with } \\
\text { uncomplicated } \\
\text { influenza }\end{array}$ & $\begin{array}{l}\text { Influenza } A(\mathrm{HINI}) \\
A(\mathrm{H} 3 \mathrm{~N} 2) \\
\text { or } B\end{array}$ & $\begin{array}{l}\text { Randomized to } 5 \text { days of treatment } \\
\text { with either peramivir ( } 400 \mathrm{mg} \text { or } \\
200 \mathrm{mg} \text { ) administered once daily } \\
\text { or oral oseltamivir ( } 75 \mathrm{mg} \text { ). }\end{array}$ & 137 & $\begin{array}{l}\text { Reduction in viral titers } \\
\text { observed after } 48 \text { hours. }\end{array}$ \\
\hline Phase III & $\begin{array}{l}\geq 6 \text { years of age; } \\
\text { hospitalized }\end{array}$ & 2009 A (HINI) & $\begin{array}{l}\text { Open-label randomized trial, } \\
5-10 \text { days treatment with } \\
\text { intravenous } 300 \mathrm{mg} \text { twice daily } \\
\text { or } 600 \mathrm{mg} \text { once daily peramivir. }\end{array}$ & 234 & $\begin{array}{l}\text { Time-weighted change in } \\
\text { influenza virus titer from } \\
\text { screening/baseline to } \\
48 \text { hours, as measured } \\
\text { by log } 10 \text { TCID50. }\end{array}$ \\
\hline Phase II & $\begin{array}{l}\text { Outpatient; } \\
\text { 20-64 years }\end{array}$ & Seasonal flu $A$ and $B$ & $\begin{array}{l}\text { Randomized, double-blind, placebo- } \\
\text { controlled trial; a single dose of } \\
\text { intravenous peramivir ( } 300 \mathrm{mg} \text { or } \\
600 \mathrm{mg} \text { ) or a matching placebo. }\end{array}$ & 298 & $\begin{array}{l}\text { Time to alleviation } \\
\text { of symptoms from the } \\
\text { start of treatment. }\end{array}$ \\
\hline Phase III & $\begin{array}{l}\text { Uncomplicated } \\
\text { influenza } \geq 20 \text { years } \\
\text { of age }\end{array}$ & $\begin{array}{l}\text { Seasonal flu } A \text { and } B \text {, } \\
\text { influenza } A(\mathrm{HINI}) \\
A(\mathrm{H} 3 \mathrm{~N} 2) \\
\text { or } B\end{array}$ & $\begin{array}{l}\text { A three-armed, multicenter, } \\
\text { randomized, double-blind, } \\
\text { multinational study. A single } \\
\text { dose of intravenous peramivir } \\
\text { (either } 300 \mathrm{mg} \text { or } 600 \mathrm{mg} \text { ) was } \\
\text { compared to a } 5 \text {-day regimen } \\
\text { of } 75 \mathrm{mg} \text { of oral oseltamivir BID. }\end{array}$ & $|, 09|$ & $\begin{array}{l}\text { Time to alleviation } \\
\text { of symptoms from the } \\
\text { start of treatment. }\end{array}$ \\
\hline
\end{tabular}




\begin{tabular}{|c|c|c|c|c|}
\hline Results & Conclusions & First author & $\begin{array}{l}\text { Reference/detailed } \\
\text { description }\end{array}$ & $\begin{array}{l}\text { Location/sponsor/ } \\
\text { trial number }\end{array}$ \\
\hline $\begin{array}{l}\text { Reduction of the plasma } \\
\text { concentration of peramivir was } \\
\text { similar across all dose groups. } \\
\text { No serious adverse events } \\
\text { occurred. }\end{array}$ & $\begin{array}{l}\text { Up to } 8 \mathrm{mg} / \mathrm{kg} / \text { day for } \\
\mathrm{I}-10 \text { days might be well } \\
\text { tolerated. }\end{array}$ & Beigel & 112 & $\begin{array}{l}\text { US/BioCryst } \\
\text { Pharmaceuticals, Inc./ } \\
\text { BCXI8I2-I0I, - I02, - } 103\end{array}$ \\
\hline $\begin{array}{l}\text { No evidence of drug accumulation } \\
\text { over either } 5 \text { days or } 10 \text { days. }\end{array}$ & $\begin{array}{l}\text { In the elderly group, } \\
\text { acceptable safety profile } \\
\text { with the multiple-day, } \\
\text { twice-daily intravenous } \\
\text { administration of peramivir }\end{array}$ & Collis & 113 & $\begin{array}{l}\text { US/BioCryst } \\
\text { Pharmaceuticals, Inc./ } \\
\text { BCXI8I2-I04 }\end{array}$ \\
\hline $\begin{array}{l}\text { Concentrations of peramivir were } \\
\text { found to exceed the IC } 50 \text { values } \\
\text { for influenza } A \text { and B strains for } \\
\text { up to } 24 \text { hours for each dose. }\end{array}$ & $\begin{array}{l}\text { Peramivir inhibited the } \\
\text { replication of the influenza } \\
\text { virus during this period. }\end{array}$ & Alexander & 114 & $\begin{array}{l}\text { US/BioCryst } \\
\text { Pharmaceuticals, Inc./ } \\
\text { BCXI8I2-103 }\end{array}$ \\
\hline $\begin{array}{l}\text { No statistically significant differences } \\
\text { between treatment groups for the } \\
\text { time to alleviation of symptoms } \\
\text { (primary endpoint) } \\
\text { Improvement over placebo was } \\
22.9 \text { hours with the } 150 \mathrm{mg} \text { dose } \\
\text { and } 21.1 \text { hours with the } 300 \mathrm{mg} \text { dose. }\end{array}$ & & NA & 115 & $\begin{array}{l}\text { US, Australia, Canada/ } \\
\text { BioCryst Pharmacueticals, } \\
\text { Inc./NCT004I9263 }\end{array}$ \\
\hline $\begin{array}{l}\text { No statistically significant differences } \\
\text { between treatment groups for } \\
\text { the time to alleviation of symptoms } \\
\text { (primary endpoint). The median } \\
\text { time to alleviation was } 91.1 \text { hours } \\
\text { for a } 600 \mathrm{mg} \text { intramuscular Injection } \\
\text { of peramivir and } 106.1 \text { hours } \\
\text { for placebo. }\end{array}$ & $\begin{array}{l}\text { Peramivir is generally } \\
\text { safe and well tolerated. }\end{array}$ & Atiee & 116 & $\begin{array}{l}\text { US, Australia, New } \\
\text { Zealand, South Africa/ } \\
\text { BioCryst Pharmaceuticals, } \\
\text { Inc./NCT00705406 }\end{array}$ \\
\hline $\begin{array}{l}\text { Titers of influenza A viruses } \\
\text { in nasopharyngeal specimens } \\
\text { decreased in a similar manner, } \\
\text { but more rapid decreases in titers } \\
\text { of influenza B with peramivir were } \\
\text { noted. }\end{array}$ & $\begin{array}{l}\text { Treatment of acute seasonal } \\
\text { influenza in hospitalized } \\
\text { adults with either peramivir } \\
\text { or oseltamivir, resulting } \\
\text { in generally similar clinical } \\
\text { outcomes. }\end{array}$ & Ison & 26 & $\begin{array}{l}\text { US, Australia, Canada, } \\
\text { Hong Kong, New Zealand, } \\
\text { Singapore, South Africa/ } \\
\text { BioCryst Pharmaceuticals, } \\
\text { Inc./NCT00453999 }\end{array}$ \\
\hline $\begin{array}{l}\text { Viral titers declined without } \\
\text { differences. }\end{array}$ & $\begin{array}{l}\text { Once- or twice-daily } \\
\text { administration was } \\
\text { associated with decreases } \\
\text { in viral shedding and clinical } \\
\text { improvement. }\end{array}$ & Ison & 24 & $\begin{array}{l}\text { US, Australia, Canada, } \\
\text { New Zealand, Mexico, } \\
\text { Puerto Rico/BioCryst } \\
\text { Pharmaceuticals, Inc. and } \\
\text { US DHHS/NCT00957996 }\end{array}$ \\
\hline $\begin{array}{l}\text { Peramivir significantly reduced } \\
\text { the time to alleviation of symptoms } \\
\text { when compared with placebo. }\end{array}$ & $\begin{array}{l}\text { A single intravenous dose } \\
\text { of peramivir is effective } \\
\text { and well tolerated. }\end{array}$ & Kohno & 23 & $\begin{array}{l}\text { Japan/ } \\
\text { Shionogi \& Company, } \\
\text { Limited/0722T062 I }\end{array}$ \\
\hline $\begin{array}{l}\text { The median durations of influenza } \\
\text { symptoms were } 78.0 \text { hours, } \\
81.0 \text { hours, and } 81.8 \text { hours } \\
\text { in the groups treated with } 300 \mathrm{mg} \\
\text { of peramivir, } 600 \mathrm{mg} \text { of peramivir, } \\
\text { and oseltamivir. }\end{array}$ & $\begin{array}{l}300 \mathrm{mg} \text { and } 600 \mathrm{mg} \text { peramivir } \\
\text { groups were not inferior to } \\
\text { the oseltamivir group. A single } \\
\text { intravenous dose of peramivir } \\
\text { may be an alternative to a } \\
5 \text {-day oral dose of oseltamivir } \\
\text { for patients with seasonal } \\
\text { influenza virus infection. }\end{array}$ & Kohno & 11 & $\begin{array}{l}\text { Japan, South } \\
\text { Korea, Taiwan/ } \\
\text { Shionogi \& Company, } \\
\text { Limited/08I5T06 3I }\end{array}$ \\
\hline
\end{tabular}


Table I (Continued)

\begin{tabular}{|c|c|c|c|c|c|}
\hline Trial & Cohort (age) & Type & Study design & $\begin{array}{l}\text { Number of } \\
\text { subjects }\end{array}$ & Primary outcome \\
\hline Phase III & $\begin{array}{l}\text { Influenza patients } \\
\text { at high risk } \\
\text { of serious } \\
\text { complications }\end{array}$ & $\begin{array}{l}\text { Seasonal flu } A \text { and } B \\
\text { influenza } A(H I N I) \text {, } \\
A(H 3 N 2) \\
\text { or } B\end{array}$ & $\begin{array}{l}\text { Uncontrolled double-blind, } \\
\text { multicenter, administered } \\
\text { intravenous peramivir over } \\
\text { multiple days at } 300 \mathrm{mg} / \text { day } \\
\text { or } 600 \mathrm{mg} / \text { day.* }\end{array}$ & 37 & $\begin{array}{l}\text { Time to alleviation } \\
\text { of symptoms from the } \\
\text { start of treatment. }\end{array}$ \\
\hline Phase III & $\begin{array}{l}\geq 28 \text { days to } \\
<16 \text { hospitalized }\end{array}$ & 2009 A (HINI) & $\begin{array}{l}\text { Multicenter, open-label, } \\
\text { uncontrolled study; } 10 \mathrm{mg} / \mathrm{kg} \\
(600 \mathrm{mg} \text { maximum) of intravenous } \\
\text { peramivir once daily for up to } \\
5 \text { days. }\end{array}$ & 106 & $\begin{array}{l}\text { Efficacy, safety, and } \\
\text { pharmacokinetics } \\
\text { of a single intravenous } \\
\text { dose of peramivir } \\
\text { in children. }\end{array}$ \\
\hline
\end{tabular}

Note: *The duration of administration was adjusted (up to 5 days) on a case-by-case basis, depending on the patient's temperature and clinical condition.

Abbreviations: BID, twice daily; IC50, 50\% inhibitory concentration; RIDT, rapid influenza diagnostic test; TCID50, tissue culture-infective dose 50; US DHHS, United States Department of Health and Human Services; NCT, National Clinical Trial; NA, not applicable as not yet published.

South Korea. The median durations of influenza symptoms were 78.0 hours, 81.0 hours, and 81.8 hours, respectively, in groups treated with $300 \mathrm{mg}$ of peramivir, $600 \mathrm{mg}$ of peramivir, and $75 \mathrm{mg}$ oseltamivir, orally twice a day. The fever lasted for $<34$ hours in patients treated with peramivir, but 37 hours in patients treated with oseltamivir, as shown in Figure 1, demonstrating that peramivir is not inferior to oseltamivir for treating seasonal influenza A and B (Table 1). ${ }^{11}$ A Phase III study comparing oseltamivir to intravenously administered zanamivir in hospitalized patients is underway. ${ }^{24}$

\section{Clinical studies of people at high risk}

for developing flu-related complications

The safety and efficacy of peramivir use were evaluated for patients under CDC-defined high-risk conditions: children younger than 5 years old, but especially children younger than 2 years old; adults 65 years of age and older; and pregnant women.

\section{Dose-response study of high-risk adults}

In a multicenter, uncontrolled, randomized, double-blind Phase III study, ${ }^{25} 300 \mathrm{mg}$ or $600 \mathrm{mg}$ of peramivir was administered intravenously once daily for 1-5 days, depending on the disease condition, to 37 adult influenza patients who were at high risk of developing severe flu-related complications. The hazard ratio ( $90 \%$ confidence interval [CI]) for the 600 $\mathrm{mg}$ group compared to the $300 \mathrm{mg}$ group was 0.497 (90\% CI: $0.251-0.984)$. The median duration of influenza illness was 68.6 hours ( $90 \%$ CI: $41.5-113.4$ ) overall. The 42.3 -hour $(90 \%$ CI: $30.0-82.7)$ result for the $600 \mathrm{mg}$ group was significantly shorter than the 114.4-hour (90\% CI: 140.2-235.3) result in the $300 \mathrm{mg}$ group (Table 1). ${ }^{25}$
Ison et $\mathrm{al}^{26}$ conducted a multinational Phase II randomized, double-blind trial in seven countries to evaluate the efficacy and safety of intravenously administered peramivir compared to oral oseltamivir in 2007-2008, the prepandemic era. The 137 adult hospitalized patients with suspected acute seasonal influenza were randomized to 5-day treatments with intravenously administered peramivir (400 mg or 200 $\mathrm{mg}$ once daily) or oral oseltamivir (75 $\mathrm{mg}$ twice daily). The median time $(95 \% \mathrm{CI})$ to clinical stability was 24.3 hours (95\% CI: $21.2-47.5$ ) with peramivir $400 \mathrm{mg}, 31.0$ hours $(95 \%$ CI: $17.2-47.7)$ with peramivir $200 \mathrm{mg}$, and 35.5 hours $(95 \%$ CI: $23.3-37.9)$ with oseltamivir $(P=0.541)$. No significant difference was found among the three treatments (Table 1). ${ }^{26}$ However, a Phase III, multicenter, randomized, double-blind, controlled study to evaluate the efficacy and safety of intravenously administered peramivir and standard care compared to standard care alone in adults and adolescents hospitalized for severe influenza was terminated by the study's Data Monitoring Committee because of futility. ${ }^{24,27}$

\section{Dose-response study of children}

Table 1 shows two studies that specifically examined the safety and efficacy of peramivir treatment in children: one study examined 106 children in one Phase III trial; ${ }^{12} 234$ patients including four adolescents (12-17 years of age) were examined in the other Phase III trial. ${ }^{24}$ No other reports describe clinical trials of peramivir in children. ${ }^{28}$ Relevant information for ongoing clinical trials sponsored by BioCryst Pharmaceuticals, Inc. is available at the clinicaltrials. gov Website.

The five completed, three terminated, three withdrawn, and one unknown trials among the 12 trials are shown and summarized based on the Cochrane Database Systematic 


\begin{tabular}{|c|c|c|c|c|}
\hline Results & Conclusions & First author & $\begin{array}{l}\text { Reference/detailed } \\
\text { description }\end{array}$ & $\begin{array}{l}\text { Location/sponsorl } \\
\text { trial number }\end{array}$ \\
\hline $\begin{array}{l}\text { The overall median duration of } \\
\text { influenza illness was } 68.6 \text { hours. } \\
\text { The duration of illness was } \\
\text { significantly shorter in the } 600 \mathrm{mg} \\
\text { group than in the } 300 \mathrm{mg} \text { group. }\end{array}$ & $\begin{array}{l}\text { The efficacy of single } \\
\text { and multiple intravenous } \\
\text { doses of peramivir is } \\
\text { comparable to oseltamivir. } \\
\text { Potentially useful for high-risk } \\
\text { patients. }\end{array}$ & Kohno & 25 & $\begin{array}{l}\text { Japan/Shionogi \& } \\
\text { Company, Limited/ } \\
\text { 0816T06 } 32 .\end{array}$ \\
\hline $\begin{array}{l}\text { The median time to the alleviation } \\
\text { of influenza symptoms was } \\
29.1 \text { hours. Virus-positive children } \\
\text { decreased to } 10 \% \text { on day } 6 \text {. }\end{array}$ & $\begin{array}{l}\text { Peramivir is clinically } \\
\text { and virologically effective } \\
\text { and safe in children with } \\
\text { pHINI virus infection. }\end{array}$ & Sugaya & 12 & $\begin{array}{l}\text { Japan/ } \\
\text { Shionogi \& Company, } \\
\text { Limited/0918T0633 }\end{array}$ \\
\hline
\end{tabular}

Review, with modification in Table $2 .{ }^{15}$ Detailed reviews of trials conducted during this period are also available. ${ }^{21,22,29}$

\section{Pandemic 2009}

The emergence of the influenza pandemic led to new guidelines that recommended antiviral treatment for all adults hospitalized with influenza, including pregnant women. Those guidelines were published on December 7, 2009 and were accepted on January 1, 2010. ${ }^{30}$ The EUA allowed health care providers to use peramivir, subject to stringent conditions. ${ }^{14}$

A few patients received peramivir or intravenously administered zanamivir, for which the FDA had issued the EUA for treatment of severe $\mathrm{pH} 1 \mathrm{~N} 1$ infections during the pandemic (from September 2009 through to June 23, 2010). Many peramivir recipients treated under the EUA were critically ill and at risk for influenza-related complications. Detailed reviews for the trials conducted during this period are available in the literature. ${ }^{21,22,28,29}$

In a dose-response study of high-risk patients, an openlabel randomized trial was conducted on 234 hospitalized patients over 6 years of age, predominantly with $\mathrm{pH} 1 \mathrm{~N} 1 .^{24}$ Patients were randomized to groups receiving $300 \mathrm{mg}$ twice daily or $600 \mathrm{mg}$ once daily of intravenously administered peramivir. Changes in nasopharyngeal viral titers from baseline to 48 hours were evaluated, as was the time to clinical resolution. No significant difference in clinical or virological effects was found between the groups (Table 1). ${ }^{24}$

The efficacy and safety of intravenously administered peramivir has been demonstrated in children with the 2009 influenza A (H1N1) virus infection. Sugaya et a $1^{12}$ conducted a multicenter, open-label, uncontrolled study to investigate the efficacy, safety, and pharmacokinetics after the once-daily intravenous infusion of $10 \mathrm{mg} / \mathrm{kg}$ (600 mg maximum) of peramivir in 106 pediatric patients infected with the $\mathrm{pH} 1 \mathrm{~N} 1$ virus, as confirmed by polymerase chain reaction. Results showed equal effectiveness of peramivir in all age groups. The median time to the alleviation of symptoms was 29.1 hours (95\% CI: 22.1-32.4). The proportion of the 106 children who were virus-positive was $78.2 \%$ on day 2 after the start of treatment. It had decreased to $7.1 \%$ on day 6 after the treatment. ${ }^{12}$ For $\mathrm{pH} 1 \mathrm{~N} 1$ virus infection, the efficacy and safety in children were expected to be similar to those in adults. This clinical report is the first of a study conducted with children. ${ }^{12}$

Approximately 60.8 million cases, 274,304 hospitalizations, and 12,469 deaths are estimated to have occurred in the US because of $\mathrm{pH} 1 \mathrm{~N} 1 .{ }^{31}$ In the US, peramivir was used under EUA for hospitalized patients who had been infected with pH1N1. Data show that 1,274 patients (median age: 43 years; range: $0-92$ years; $49 \%$ male) received $\geq 1$ dose of peramivir for 6 days of median duration. ${ }^{32}$ Therefore, approximately $0.46 \%$ of hospitalized patients might have been treated with peramivir based on the estimated 274,304 hospitalizations attributable to $\mathrm{pH} 1 \mathrm{~N} 1$. A clinical study evaluating the efficacy and safety of peramivir treatment among hospitalized adults and children with influenza was done in the US. ${ }^{14}$ All subjects received peramivir under EUA. Only some clinical data have been published (Table 3).

Shrestha et $\mathrm{al}^{31}$ estimated that $\mathrm{pH} 1 \mathrm{~N} 1$ deaths occurred in people younger than 65 years of age, with children and working adults having risks for hospitalization and death that were 4-7 times and 8-10 times greater, respectively, than the estimates for seasonal influenza in the years from 1976-2001.

Antiviral treatment increased during the pandemic. Doshi et $a l^{33}$ compared antiviral use among adults hospitalized with influenza before and during the pandemic from 


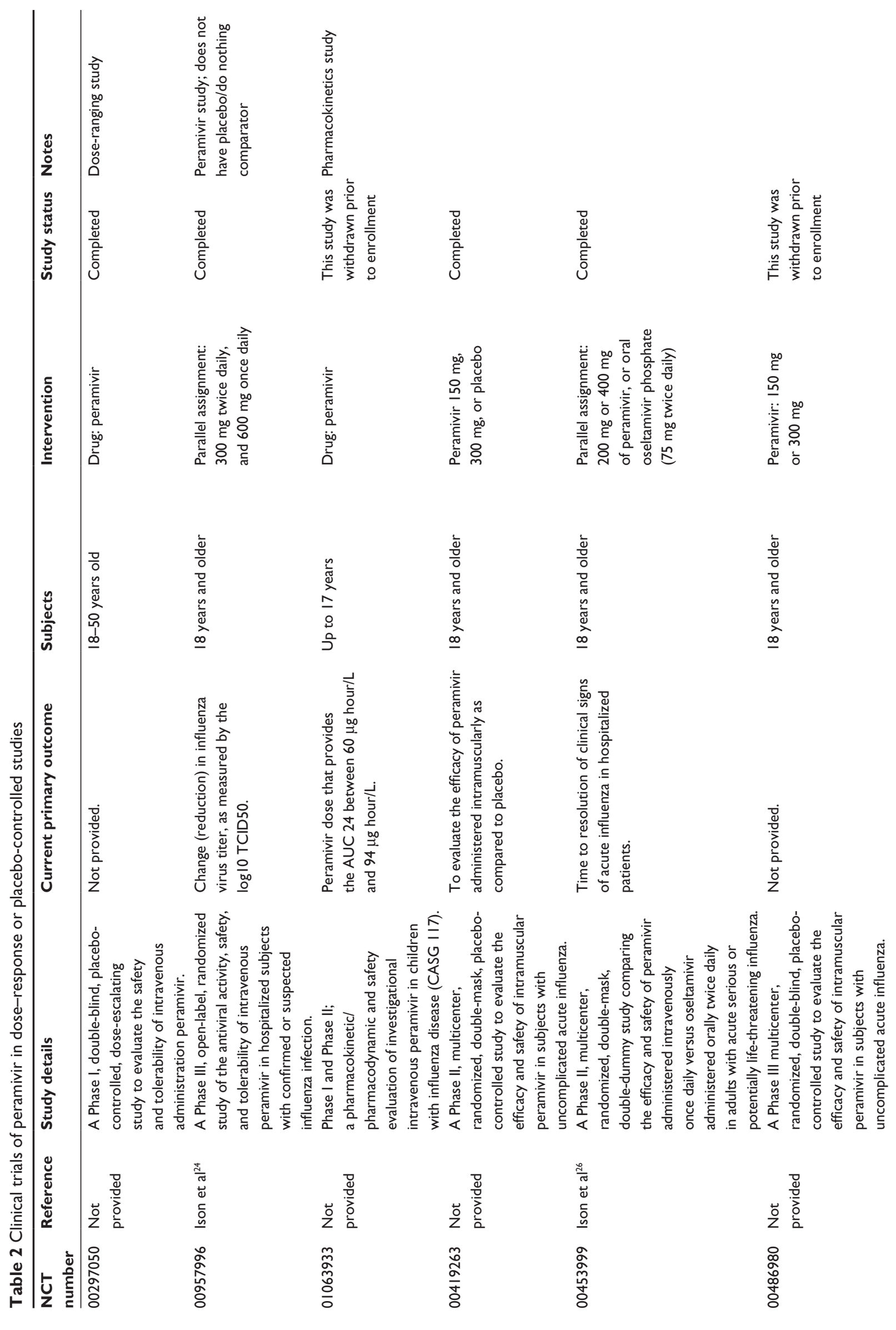



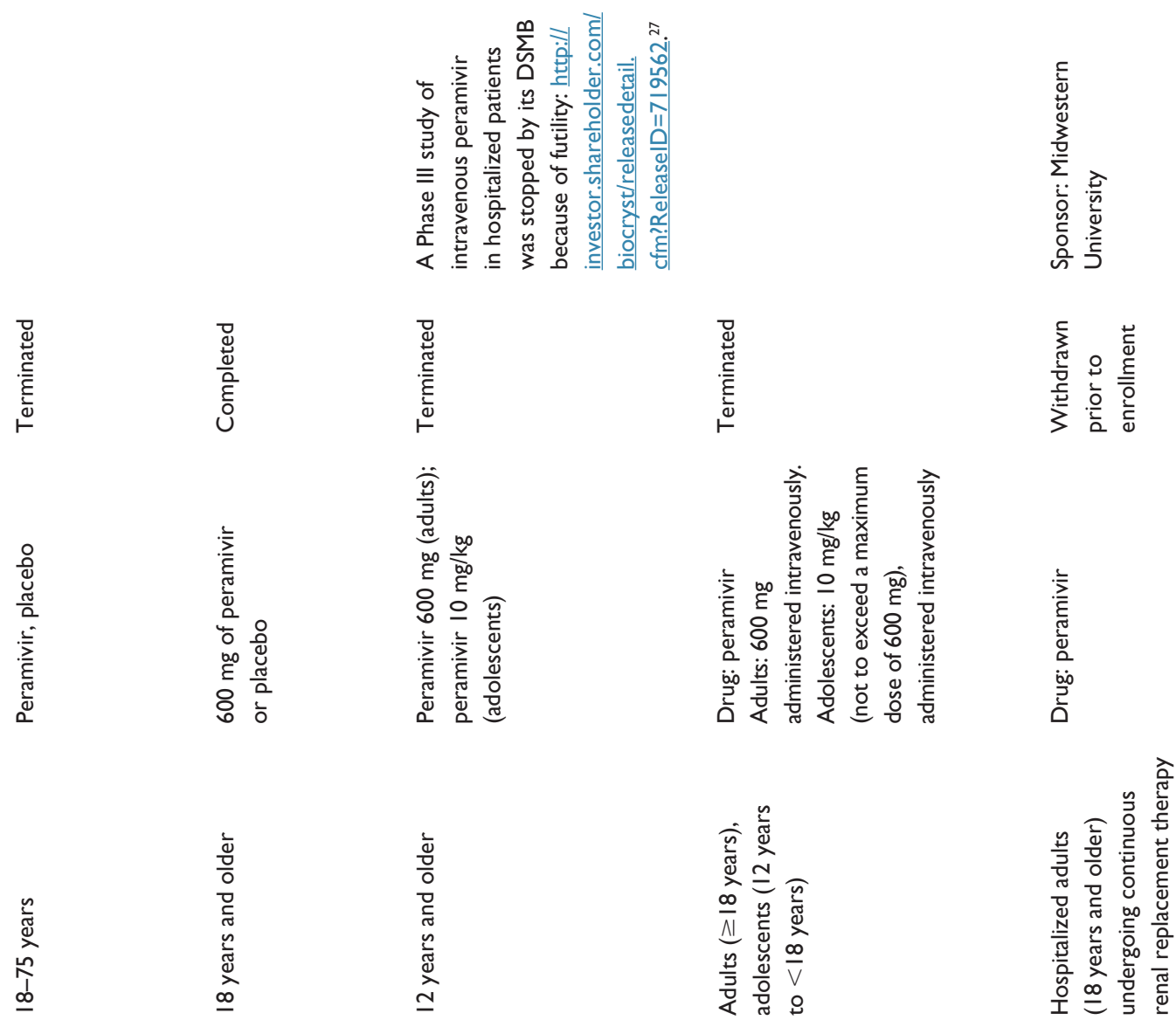

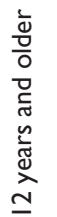
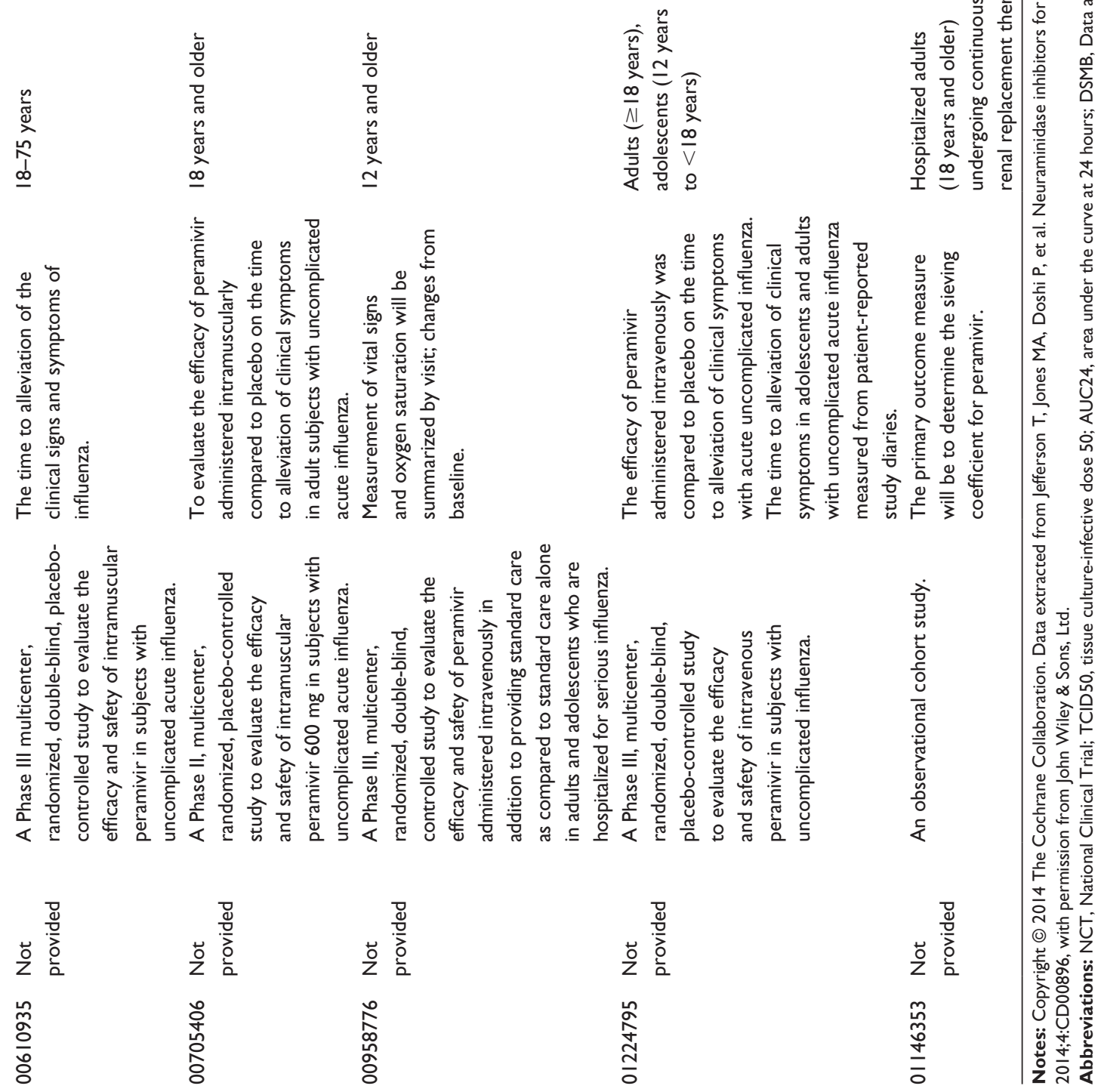


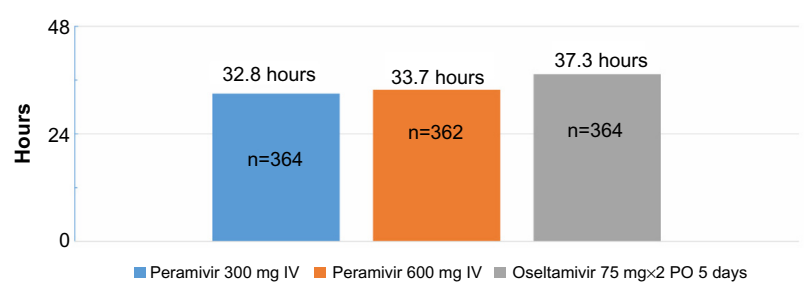

Figure I Mean duration of fever after onset.

Notes: The median time required for patients' body temperatures to return to normal (ITTI) is shown. Analyzed using a Cox proportional hazards model. The ITTI returned to a normal temperature $\left(<37^{\circ} \mathrm{C}\right)$, and it remained for more than 12 hours. Copyright (02013 Shionogi \& Co., Ltd. Adapted from Fever lasting for less than 34 hours in patients treated with peramivir [pamphlet]. Osaka: Shionogi \& Co., Ltd.; $2013 .^{10}$ Data are from a multinational, randomized, double-blind Phase III study in Japan, Taiwan, and South Korea."

Abbreviations: ITTI, intent-to-treat infected; n, number; IV, intravenous; PO, per os.

data collected via medical record reviews of patients aged $\geq 18$ years admitted during the prepandemic and pandemic eras in ten states. When compared to use in prepandemic seasons, antiviral treatments of hospitalized adults increased from $54 \%$ to $82 \%$, especially in pregnant women, for whom treatments increased from $22 \%$ to $86 \%$ during the pandemic. ${ }^{33}$ Fry et al ${ }^{34}$ reported the frequency and characteristics of patients who received NAI based on surveillance data in areas that included 22 million adults and children from selected counties in ten states, representing approximately $7 \%$ of the US population. The results showed that 46,216 patients $(80 \%)$ had documented receipt of an NAI. Among those who received an NAI, $0.2 \%$ of children and $1 \%$ of adults received an NAI intravenously, 33 received peramivir (one child), and eight received zanamivir intravenously (two children). ${ }^{34}$ Very few people had been given peramivir.

Hernandez et al,,$^{35}$ on behalf of BioCryst Pharmaceuticals, Inc., which provided peramivir under FDA Emergency Investigational New Drug (eIND) regulations, first characterized 20 adults and eleven children who received peramivir at the beginning of the pandemic based on data collected using a standardized case report from April-October 2009: all patients had pneumonia with respiratory failure; 30 of 31 required mechanical ventilation; 17 continued oseltamivir treatment after peramivir initiation; and 12 patients died because of major organ failure or the exacerbation of underlying conditions. Early peramivir treatment was related to higher survival in the population of pediatric, pregnant, or postpartum patients. Results showed that ten patients who recovered received peramivir starting on hospital day $2-8$, although the four patients who died received peramivir starting on hospital day $10-16 .{ }^{35} \mathrm{Jain}$ et $\mathrm{al}^{36}$ reported that these data cannot be related to the effectiveness of intravenously administered peramivir in severely ill persons infected with influenza because most of them (87\%) received concurrent oseltamivir, and there was no comparison group. Patients had been hospitalized for a median of 4 days (range, 1-24 days) before the initiation of peramivir, and they had been treated for 1-14 days (median duration, 10 days). Patients who recovered were discharged from the hospital after 8-117 days (median duration, 25 days). ${ }^{35}$ The median time from symptom onset to peramivir treatment was not described. It is difficult to ascertain the precise effect of peramivir. Further studies must assess its clinical effectiveness and safety because peramivir recipients under the EUA were critically ill and were at high risk for influenza-related complications. ${ }^{37,38}$

Early treatment was ideal, but it was difficult to initiate antiviral drug use in facilities that had a request under the EUA. Randolph et al ${ }^{39}$ reported that only 5.8\% (49 of 838) of patients had received antiviral medications before pediatric intensive care unit (PICU) admission. Louie et a ${ }^{137}$ examined 784 influenza patients under 18 years of age who had been hospitalized in intensive care units (ICUs), and they additionally described 57 critically ill adults and pediatric patients treated with peramivir for $\mathrm{pH} 1 \mathrm{~N} 1$ virus infection in California. The median (range) time from symptom onset to antiviral treatment out of the total number of patients who received peramivir (number $[\mathrm{n}]=57)$, fatal patients $(\mathrm{n}=29)$, and nonfatal patients $(\mathrm{n}=28)$ were, respectively, 4 days ( $0-23$ days), 5 days ( $0-23$ days), and 4 days ( $0-9$ days). The median (range) time from symptom onset to peramivir treatment of the total peramivir patients $(\mathrm{n}=57)$, fatal patients, and nonfatal patients were, respectively, 9 days (2-38 days), 10 days (2-36 days), and 9 days ( $2-38$ days). The high mortality rate, approximately $50 \%$, was attributed to the pre-existing clinical severity of cases before the request for peramivir. ${ }^{37}$

The pH1N1-related PICU mortality rates were $7 \%-39 \%$ in Canada, Australia, New Zealand, and Argentina. ${ }^{40-42}$ Independent risk factors associated with fatal outcomes have not been well established because of smaller sample sizes. ${ }^{38,39,43,44}$ Critically ill patients with a median age of 40 years ( 5 months to 81 years) with pH1N1 virus infection in California were also evaluated. In all, 29 (51\%) of the 57 hospitalized peramivir recipients in the ICUs died. The median time from symptom onset to peramivir treatment was 8 days (1-22 days). The 10 days (2-36 days) noted among fatal cases were not compared with the 9 days (2-38 days) among the nonfatal cases. High mortality rates might not be attributable to late peramivir treatment, but rather to the pre-existing clinical severity level; greater deterioration of the patient's condition occurred following oral oseltamivir treatment in ICUs. ${ }^{37}$ Louie et a ${ }^{143}$ reported that antiviral treatment was significantly associated with decreased mortality (odds ratio $=0.38 ; 95 \%$ CI: $0.17-0.87$ ). Children treated earlier in their illness were less likely to die than those who 
were treated later. In particular, antiviral treatment within 48 hours of illness onset was significantly associated with survival $(P=0.04)$. The results suggest that prompt treatment with NAIs might improve the survival of children who are critically ill with influenza. ${ }^{43}$ Antiviral drugs are expected to be most effective within 48 hours from symptom onset. ${ }^{44}$ Further investigations must evaluate the safety and effectiveness of peramivir in hospitalized and critically ill patients.

\section{Postpandemic 2009}

The pH1N1 influenza virus has moved into the postpandemic period. Localized outbreaks of various magnitudes continue every year as seasonal influenza.

The world's first approval of peramivir was granted by the Ministry of Health, Labour and Welfare in Japan in late January 2010, so that its intravenous administration would benefit many influenza patients. ${ }^{45,46}$ Peramivir was approved by the Korean FDA in August 2010.

Because the EUA expired on June 23, 2010, when the pandemic ended, peramivir is only currently available in Japan and South Korea. Postmarketing product surveillance demonstrated that the clinical efficacy of peramivir is not inferior to that of other NAIs for the treatment of seasonal influenza (Figure 1). ${ }^{11}$ Results obtained from some clinical studies show that peramivir is more effective in alleviating influenza symptoms than are other NAIs (Table 3). ${ }^{39,47}$ After the pandemic, a few retrospective clinical studies of adults and children were performed only in Japan, where peramivir has been used at the discretion of physicians since its approval on January $2010 .^{38,39,43,47}$ In a retrospective observational study conducted during the 2010-2011 influenza season, 263 pediatric influenza patients receiving oseltamivir, zanamivir, laninamivir, or peramivir were analyzed. In A (H3N2)-infected patients, the median duration of fever in the oseltamivir group was 3.3 times longer than in the peramivir group $(P=0.0303)$. Peramivir treatment is likely to show its greatest effectiveness in reducing the duration of symptoms. ${ }^{48}$ Similar results were obtained from a retrospective study performed between February-April 2011.49 The effectiveness of treatment with NAIs (oseltamivir, peramivir, laninamivir, and peramivir) was assessed in 223 patients aged 5-18 years who had been diagnosed as having influenza A (131) or B (92) infection; this was diagnosed by the rapid influenza diagnostic test. The median duration of fever after treatment with peramivir (1 day) was significantly shorter than that after treatment with zanamivir ( 2 days) in influenza A patients $(P=0.0283)$. The median duration of fever after peramivir treatment ( 1 day) was significantly shorter than after laninamivir treatment (3 days) in influenza B patients $(P=0.0097) .{ }^{49} \mathrm{~A}$ retrospective study ${ }^{50}$ recently showed the clinical features of hospitalized adults and children with influenza who were treated with peramivir during the 2012-2013 season. The clinical efficacy of peramivir was evaluated in 32 hospitalized adult influenza patients with underlying diseases, and the treatment was administered within 48 hours of disease onset - either $300 \mathrm{mg}$ of peramivir administered once daily or $75 \mathrm{mg}$ of oseltamivir administered for 5 days twice daily during 2012-2013. The treatment was chosen by the physician in accordance with the patient's medical condition. No significant difference was found between the peramivir (30.9 hours) and oseltamivir (34.7 hours) groups in terms of the median time to defervescence. ${ }^{50}$ Peramivir appeared to be as efficacious as oseltamivir. These studies were retrospective, nonrandomized, without placebo, not controlled, and with a small sample size. The studies were performed only to compare the effects among NAIs. Although not of high quality, these studies underscore the clinical effectiveness of peramivir, which had already been demonstrated during its nationwide use in many facilities in Japan when used within 48 hours of disease onset. ${ }^{111}$

\section{Clinical safety}

\section{Adverse effects of neuraminidase inhibitors}

Adverse effects of NAIs in uncomplicated adult patients are typically mild. ${ }^{51}$ Nausea and vomiting have been the most conspicuous adverse effects in oseltamivir trials in healthy adults. ${ }^{52,53}$ No significant adverse effects were recorded in treatment trials with zanamivir in healthy adults. ${ }^{15,52}$ In children and at-risk individuals treated with oseltamivir or zanamivir, no significant drug-related or severe adverse effects were found. ${ }^{53}$ Zanamivir can cause acute bronchospasm and severe declines in respiratory function among patients with or without a previous history of asthma or chronic obstructive pulmonary disease, although the frequency is not clear. ${ }^{54,55}$ For one trial, Wang et $\mathrm{al}^{56}$ described study results whereby gastrointestinal symptoms were related to the adverse effects of laninamivir treatment in children. Other AEs, including neuropsychiatric AEs were observed occasionally in influenza patients receiving oseltamivir. ${ }^{57,58}$ Sudden death was reported as an AE related to oseltamivir. ${ }^{59,60}$ The effects of influenza infection itself and/or drug-disease interactions should be considered. However, for the US and Japan, neuropsychiatric AEs were reported significantly less often during the pandemic than during the previous influenza seasons. ${ }^{51}$

\section{Adverse effects of peramivir Uncomplicated adults}

Kohno et al conducted a dose-ranging Phase I study of intravenously administered peramivir at up to $800 \mathrm{mg}$ once daily 
Table 3 Characteristics of clinical studies of peramivir for the treatment of adult and pediatric patients with influenza infection

\begin{tabular}{|c|c|c|c|c|c|c|}
\hline Year & Type & Study design & Age & $\mathbf{N}$ & Subjects & Intervention/treatment \\
\hline \multicolumn{7}{|c|}{ Adults } \\
\hline 2014 & $\begin{array}{l}2012-2013 \\
\text { seasonal flu } A \\
\text { and } B\end{array}$ & $\begin{array}{l}\text { Retrospective } \\
\text { cohort }\end{array}$ & $>18$ years & 32 & Inpatient & $\begin{array}{l}300 \mathrm{mg} \text { intravenously } \\
\text { administered once daily for } \\
\text { I day versus oral oseltamivir } \\
\text { (75 mg) twice daily for } 5 \text { days }\end{array}$ \\
\hline 2013 & $\begin{array}{l}2009 \text { A } \\
(\mathrm{HINI})\end{array}$ & $\begin{array}{l}\text { Open-label } \\
\text { randomized } \\
\text { trial }\end{array}$ & $\geq 18$ years & 234 & Inpatient & $\begin{array}{l}300 \mathrm{mg} \text { intravenously } \\
\text { administered twice daily or } \\
600 \mathrm{mg} \text { once daily for } 5 \text { days }\end{array}$ \\
\hline 2013 & $\begin{array}{l}2009 \text { A } \\
(\mathrm{HINI})\end{array}$ & $\begin{array}{l}\text { Randomized, } \\
\text { double-blind, } \\
\text { placebo- } \\
\text { controlled trial }\end{array}$ & $\geq 18$ years & 137 & Inpatient & $\begin{array}{l}\text { Intravenous } 400 \mathrm{mg} \text { or } 200 \mathrm{mg} \\
\text { once daily, or oral oseltamivir } \\
\text { ( } 75 \mathrm{mg} \text { twice daily) for } 5 \text { days }\end{array}$ \\
\hline 2011 & $\begin{array}{l}2008-2009 \\
\text { season; } \\
\text { seasonal flu } \\
\text { A and B }\end{array}$ & $\begin{array}{l}\text { Randomized, } \\
\text { double-blind } \\
\text { study }\end{array}$ & $\geq 20$ years & $|, 09|$ & $\begin{array}{l}\text { Both (coexisting } \\
\text { disease at baseline; } \\
34.9 \%-40.3 \% \text { in } \\
\text { each group) }\end{array}$ & $\begin{array}{l}\text { Intravenous } 300 \mathrm{mg} \text { or } \\
600 \mathrm{mg} \text { once daily for I day } \\
\text { versus placebo }\end{array}$ \\
\hline 2011 & $\begin{array}{l}\text { Seasonal flu } \\
A \text { and } B\end{array}$ & $\begin{array}{l}\text { Per protocol } \\
\text { set }\end{array}$ & $\geq 20$ years & 37 & $\begin{array}{l}\text { High-risk } \\
\text { inpatient }\end{array}$ & $\begin{array}{l}\text { Intravenous } 300 \mathrm{mg} \text { or } 600 \mathrm{mg} \\
\text { once daily for I-5 days }\end{array}$ \\
\hline 2010 & $\begin{array}{l}\text { Seasonal flu } \\
A \text { and } B\end{array}$ & $\begin{array}{l}\text { Randomized, } \\
\text { double-blind, } \\
\text { placebo- } \\
\text { controlled trial }\end{array}$ & $20-64$ years & 300 & Outpatient & $\begin{array}{l}300 \mathrm{mg} \text { or } 600 \mathrm{mg} \text { once daily } \\
\text { for I day }\end{array}$ \\
\hline \multicolumn{7}{|c|}{ Children } \\
\hline 2012 & $\begin{array}{l}2009 \text { A } \\
(\mathrm{HINI})\end{array}$ & $\begin{array}{l}\text { Multicenter, } \\
\text { open-label, } \\
\text { uncontrolled study }\end{array}$ & $\begin{array}{l}\geq 28 \text { days } \\
\text { to }<16 \text { years }\end{array}$ & 106 & Inpatient & $\begin{array}{l}\text { Intravenously administered } \\
10 \mathrm{mg} / \mathrm{kg} \text { ( } 600 \mathrm{mg} \text { maximum) } \\
\text { once daily }\end{array}$ \\
\hline 2012 & $\begin{array}{l}2009 \mathrm{~A} \\
(\mathrm{HINI}) \text { and } \\
\mathrm{A}(\mathrm{H} 3 \mathrm{~N} 2)\end{array}$ & $\begin{array}{l}\text { Observational } \\
\text { study }\end{array}$ & $8.8 \pm 3.9$ years & $\begin{array}{l}263(\text { oseltamivir }=104 \\
\text { peramivir }=4 \text { ) }\end{array}$ & Outpatient & $\begin{array}{l}\text { Intravenously administered } \\
10 \mathrm{mg} / \mathrm{kg}(600 \mathrm{mg} \text { maximum) } \\
\text { once daily }\end{array}$ \\
\hline 2012 & $\begin{array}{l}201 \mathrm{I} \text { seasonal } \\
\text { flu } A \text { and } B\end{array}$ & $\begin{array}{l}\text { Retrospective } \\
\text { chart review }\end{array}$ & $0-18$ years & $\begin{array}{l}\text { Total: } 223 \text { (influenza A) } \\
\text { (5-18 years); } \\
\text { oseltamivir =83; } \\
\text { peramivir = } 22 \text {. } \\
\text { Influenza B ( } 5-18 \text { years): } \\
\text { laninamivir = } 13 \text {; } \\
\text { peramivir = } 13\end{array}$ & Outpatient & $\begin{array}{l}\text { Intravenously administered } \\
10 \mathrm{mg} / \mathrm{kg} \text { ( } 300 \mathrm{mg} \text { maximum) } \\
\text { once daily }\end{array}$ \\
\hline 2011 & $\begin{array}{l}2009 \mathrm{~A} \\
(\mathrm{HINI})\end{array}$ & $\begin{array}{l}\text { Retrospective } \\
\text { chart review }\end{array}$ & $\leq 15$ years & $\begin{array}{l}\text { I,000 (four received } \\
\text { peramivir); } 660(66.0 \%) \\
\text { had no underlying } \\
\text { Illness. }\end{array}$ & Inpatient & Not described \\
\hline \multicolumn{7}{|c|}{ Critically ill/at-risk adults and children } \\
\hline 2013 & $\begin{array}{l}2009 \text { A } \\
(\mathrm{HINI})\end{array}$ & $\begin{array}{l}\text { Retrospective } \\
\text { chart review }\end{array}$ & $0-17$ years & $\begin{array}{l}784 \text { (unknown } \mathrm{N} \\
\text { treated with } \\
\text { peramivir) }\end{array}$ & Inpatient & $\begin{array}{l}\text { Of the } 784 \text { patients, } 653 \text { (83\%) } \\
\text { were treated with NAls }\end{array}$ \\
\hline 2012 & $\begin{array}{l}2009 \mathrm{~A} \\
(\mathrm{HINI})\end{array}$ & $\begin{array}{l}\text { Retrospective } \\
\text { chart review }\end{array}$ & $<1-90$ years & $\begin{array}{l}\text { Total: } 344(<18 \text { years: } \\
\text { 28; } 18-65 \text { years: } 290 ; \\
>65 \text { years: } 21)\end{array}$ & Inpatient & $\begin{array}{l}\text { The median duration of peramivir } \\
\text { administration was } 5 \text { days } \\
\text { (range: } 1-\mid 4 \text { days) }\end{array}$ \\
\hline
\end{tabular}




\begin{tabular}{|c|c|c|c|}
\hline Results & Conclusion & First author & References \\
\hline $\begin{array}{l}\text { Median TTRF: } 300 \mathrm{mg} \text { once-daily intravenous peramivir } \\
\text { treatment group versus The } 5 \text {-day oseltamivir } \\
\text { treatment group }(30.9 \pm 18.7 \text { hours versus } \\
34.7 \pm 18.6 \text { hours; } P=0.62 \text { ). }\end{array}$ & $\begin{array}{l}\text { The clinical efficacy of peramivir } \\
\text { is not inferior to that of oseltamivir. }\end{array}$ & Yoshino & 50 \\
\hline 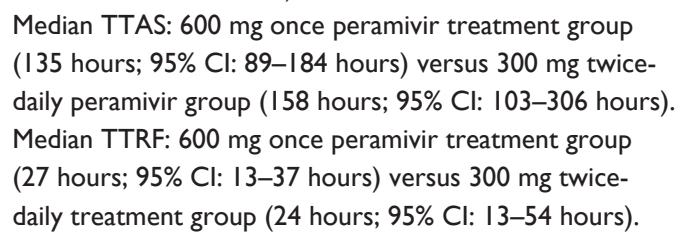 & $\begin{array}{l}600 \mathrm{mg} \text { once-daily or } 300 \mathrm{mg} \text { twice-daily } \\
\text { administration was associated with } \\
\text { decreases in viral shedding and clinical } \\
\text { improvement. }\end{array}$ & Ison & 24 \\
\hline $\begin{array}{l}\text { Median TTAS: } 400 \mathrm{mg} \text { 5-day peramivir treatment group } \\
\text { ( } 24.3 \text { hours; } 95 \% \mathrm{Cl}: 21.2-47.5 \text { hours) versus the } 200 \mathrm{mg} \\
5 \text {-day peramivir group ( } 31.0 \text { hours; } 95 \% \mathrm{Cl}: 17.2-47.7 \text { hours) } \\
\text { versus the } 75 \mathrm{mg} \text { twice-daily } 5 \text {-day oseltamivir group } \\
\text { ( } 35.5 \text { hours; } 95 \% \mathrm{Cl}: 23.3-37.9 \text { hours); } P=0.54 \mathrm{I} .\end{array}$ & $\begin{array}{l}\text { Peramivir and oseltamivir results } \\
\text { were generally similar. }\end{array}$ & Ison & 26 \\
\hline $\begin{array}{l}\text { Median TTAS: } 300 \mathrm{mg} \text { once-daily intravenous peramivir } \\
\text { treatment group ( } 78.0 \text { hours; } 95 \% \mathrm{Cl}: 68.4-88.6 \text { hours), } \\
600 \mathrm{mg} \text { once-daily intravenous peramivir treatment } \\
\text { group ( } 81.0 \text { hours; } 95 \% \mathrm{Cl}: 72.2-91.5 \text { hours), } \\
\text { and } 5 \text {-day oseltamivir treatment group } \\
\text { (81.8 hours; } 95 \% \mathrm{Cl}: 73.2-91.1 \text { hours). }\end{array}$ & $\begin{array}{l}\text { The peramivir groups were noninferior } \\
\text { to the oseltamivir group. }\end{array}$ & Kohno & 11 \\
\hline $\begin{array}{l}\text { Median TTAS: overall, } 68.6 \text { hours ( } 90 \% \mathrm{Cl} \text { : } \\
41.5-1 \mathrm{I} 3.4 \text { hours); } 300 \mathrm{mg} \text { group, I I } 4.4 \text { hours } \\
\text { ( } 90 \% \mathrm{Cl}: 40.2-235.3 \text { hours); } 600 \mathrm{mg} \text { group, } \\
42.3 \text { hours ( } 90 \% \mathrm{Cl}: 30.0-82.7 \text { hours). }\end{array}$ & $\begin{array}{l}\text { Peramivir appears to be a potentially } \\
\text { useful treatment for high-risk patients. }\end{array}$ & Kohno & 14 \\
\hline $\begin{array}{l}300 \text { mg once-daily peramivir treatment group, } \\
59.1 \text { hours ( } 95 \% \mathrm{Cl}: 50.9-72.4 \text { hours); HR } * 0.68 \mathrm{I} \\
(95 \% \mathrm{Cl}: 0.5 \mathrm{II}-0.909) ; 600 \mathrm{mg} \text { group, } 59.9 \text { hours } \\
(95 \% \mathrm{Cl}: 54.4-68.1 \text { hours). } \\
\text { HR* } 0.666 \text { ( } 95 \% \mathrm{Cl}: 0.499-0.890) .\end{array}$ & $\begin{array}{l}\text { Single intravenous dose of peramivir } \\
\text { is effective and well tolerated. }\end{array}$ & Kohno & 23 \\
\hline $\begin{array}{l}\text { Median TTAS: } 29.1 \text { hours ( } 95 \% \mathrm{Cl}: 2.1-32.4 \text { hours); } \\
\text { median TTRF: } 20.6 \text { hours ( } 95 \% \mathrm{Cl}: 19.4-21.1 \text { hours). }\end{array}$ & $\begin{array}{l}\text { Peramivir is clinically and virologically } \\
\text { effective and safe in children with } \\
\text { pHINI virus infection. }\end{array}$ & Sugaya & 12 \\
\hline $\begin{array}{l}\text { Median TTRF: zanamivir treatment group ( } 23.0 \text { hours; } \\
95 \% \text { Cl: } 22.0-24.0 \text { hours) versus the peramivir group } \\
\text { (I } 7.0 \text { hours; } 95 \% \text { Cl: } 7.2-26.8 \text { hours). }\end{array}$ & $\begin{array}{l}\text { Peramivir treatment group ( } 17.0 \text { hours; } \\
95 \% \mathrm{Cl}: 7.2-26.8 \text { hours) was significantly } \\
\text { shorter than that in the oseltamivir } \\
\text { treatment group }(P=0.044) \text {. }\end{array}$ & Shobugawa & 48 \\
\hline $\begin{array}{l}\text { Median TTRF: oseltamivir treatment group ( } 2 \text { days) } \\
\text { versus peramivir group ( } I \text { day; } P=0.0242) \text { in influenza } \\
\text { A. Laninamivir group ( } 3 \text { days) versus peramivir group } \\
\text { ( } \text { day; } P=0.0097) \text { in influenza } B \text {. }\end{array}$ & $\begin{array}{l}\text { No significant difference for any } \\
\text { of the other combinations of the } \\
\text { drug/disease type/age groups. }\end{array}$ & Hikita & 49 \\
\hline $\begin{array}{l}\text { In } 88.9 \% \text { of the patients, treatment with neuraminidase } \\
\text { inhibitors was initiated within } 48 \text { hours after the onset } \\
\text { of illness. One patient died of HINI/09 infection. }\end{array}$ & $\begin{array}{l}\text { Low mortality rate attributable } \\
\text { to the universal implementation } \\
\text { of early treatment with neuraminidase } \\
\text { inhibitors. }\end{array}$ & Sugaya & 106 \\
\hline $\begin{array}{l}\text { Of } 653 \text { NAl-treated cases, } 38(6 \%) \text { died, as compared } \\
\text { with eleven ( } 8 \%) \text { of the I } 3 \text { I untreated cases } \\
\text { (odds ratio }=0.67 ; 95 \% \mathrm{Cl}: 0.34-\mathrm{I} .36 \text { ). }\end{array}$ & $\begin{array}{l}\text { Prompt ( }<48 \text {-hour) treatment with } \\
\text { NAls may improve the survival of } \\
\text { critically ill children. }\end{array}$ & Louie & 43 \\
\hline $\begin{array}{l}76(60 \%) \text { patients were improved, eleven }(9 \%) \\
\text { were unchanged, seven }(6 \%) \text { had deteriorated } \\
\text { but not died, and } 30(24 \%) \text { had died. }\end{array}$ & $\begin{array}{l}\text { Rash was the only treatment-emergent } \\
\text { adverse event attributable to peramivir. } \\
\text { Safety data were insufficient. }\end{array}$ & Sorbello & 38 \\
\hline
\end{tabular}


Table 3 (Continued)

\begin{tabular}{|c|c|c|c|c|c|c|}
\hline Year & Type & Study design & Age & $\mathbf{N}$ & Subjects & Intervention/treatment \\
\hline 2012 & $\begin{array}{l}2009 \text { A } \\
(\mathrm{HINI})\end{array}$ & $\begin{array}{l}\text { Retrospective } \\
\text { comparative } \\
\text { analysis with or } \\
\text { without peramivir }\end{array}$ & $\begin{array}{l}5 \text { months } \\
\text { to } 81 \text { years }\end{array}$ & 57 & Inpatient & $\begin{array}{l}\text { Comparative analysis: I) critically } \\
\text { ill patients who received peramivir } \\
\text { and critically ill patients who were } \\
\text { treated with NAls but who did } \\
\text { not receive peramivir; } 2 \text { ) fatal and } \\
\text { nonfatal peramivir-treated cases }\end{array}$ \\
\hline 2012 & $\begin{array}{l}2009 \mathrm{~A} \\
(\mathrm{HINI})\end{array}$ & $\begin{array}{l}\text { Retrospective } \\
\text { report review }\end{array}$ & $0-92$ years & $\mathrm{I}, 274$ & Inpatient & $\begin{array}{l}\text { Received peramivir through the } \\
\text { EUA program }\end{array}$ \\
\hline
\end{tabular}

Abbreviations: N, number; TTRF, time to resolution of fever; TTAS, time to alleviation of influenza symptoms; $\mathrm{Cl}$, confidence interval; HR, hazard ratio; $\mathrm{NAls}$, neuraminidase inhibitor; EUA, Emergency Use Authorization.

for 6 days in healthy adults. ${ }^{23}$ Results showed that peramivir was well tolerated (Kohno et al, unpublished data, 2010). The authors evaluated the safety of a single dose of peramivir for otherwise healthy influenza outpatients. For the study, 1,091 patients with seasonal influenza $\mathrm{A}$ and $\mathrm{B}$ were randomized into one of three groups: single intravenous infusion of 300 $\mathrm{mg}$; $600 \mathrm{mg}$ of peramivir; or matching placebo. Severe AEs occurred with two subjects. One patient in the $300 \mathrm{mg}$ group had a prolonged QT interval on electrocardiogram. The other had increased blood creatinine in the $600 \mathrm{mg}$ group. Both AEs were regarded as related to the study medications. Both of these events resolved without treatment. The other severe AEs were attributed to influenza virus infection or its complications, most commonly gastrointestinal symptoms. In the $300 \mathrm{mg}$, $600 \mathrm{mg}$, and placebo groups, diarrhea occurred, respectively, in $14.1 \%, 15.2 \%$, and $17.0 \%$, and nausea in $3.0 \%, 6.1 \%$, and $1.0 \%{ }^{23}$

High-risk adults and children

In the uncontrolled, double-blind, randomized Phase III trial $^{25}$ of intravenously administered peramivir $(300 \mathrm{mg} /$ day or $600 \mathrm{mg} /$ day) for 1-5 days described previously, two of 18 patients were administered $300 \mathrm{mg}$ and 19 patients were administered $600 \mathrm{mg}$ of peramivir among 37 high-risk adult patients with seasonal influenza A or B infection. One patient developed bacterial pneumonia, and another developed pneumonia. ${ }^{25}$ In an uncontrolled double-blind, multicenter Phase III study of uncomplicated 1,091 adult influenza patients, the incidences of severe AEs, respectively, accounted for $5.2 \%, 8.2 \%$, and $6.6 \%$ of cases in the intravenous $300 \mathrm{mg}$ peramivir, $600 \mathrm{mg}$ peramivir, and oral oseltamivir groups. No difference in the incidence of severe AEs or adverse drug reactions was found among the treatment groups. The most common severe AEs were a prolonged QT interval and a decreased neutrophil count. The incidences of a prolonged QT interval and a decreased neutrophil count in the peramivir groups were similar to those in the oseltamivir group. In many of these patients, the lowest neutrophil count was observed on day 3 of peramivir administration. This count recovered more rapidly than in the oseltamivir group. The incidence of severe adverse reactions in either peramivir group was not different from that of the oseltamivir group. ${ }^{11}$

In a multinational Phase II study of 137 hospitalized adult patients in the 2007-2008 season conducted by Ison et $\mathrm{al}^{26}$ (and described in the results, and in Table 1 and 3), the overall incidences of AEs were $52 \%, 56 \%$, and $41 \%$, respectively, in the groups treated with $400 \mathrm{mg}$ or $200 \mathrm{mg}$ of peramivir or $75 \mathrm{mg}$ of oseltamivir. The incidence was higher in the peramivir groups than in the oseltamivir group, mainly because of the frequency of diarrhea, but the incidence of severe adverse reactions in either peramivir group resembled that in the oseltamivir group. ${ }^{26}$

The reports that will be described next are related to the situation of the pandemic. Hernande $z^{35}$ reported data for 31 patients who had received peramivir for 2-15 days. No general or severe AEs were attributable to peramivir. ${ }^{35}$ Sorbello et $\mathrm{al}^{38}$ evaluated the safety of intravenously administered peramivir for suspected or confirmed $\mathrm{pH} 1 \mathrm{~N} 1$ virus infection. Safety surveillance was limited because clinical reports were submitted to the US FDA Adverse Event Reporting System. The FDA safety team analyzed reports submitted to the Adverse Event Reporting System. From October 23, 2009 to June 23, 2010, data were processed for at least 1,274 patients who received $\geq 1$ dose of peramivir. A report of 344 patients (median age 45 years [ $<1-90$ years], including 28 children and three pregnant women) described rash as the only treatment-emergent $\mathrm{AE}$ attributable to peramivir. The high mortality rate $(15 \% ; 53$ of 344 patients) and the development of acute respiratory distress syndrome ( $7 \% ; 25$ of 344 patients) were likely to account for part of the severity of the patients' influenza A infection. Renal failure ( $5 \% ; 17$ of 344 patients) was commonly reported, probably 


\begin{tabular}{|c|c|c|c|}
\hline Results & Conclusion & First author & References \\
\hline $\begin{array}{l}29(5 \mathrm{I}) \text { peramivir recipients died. Peramivir recipients } \\
\text { were more likely to die }(P \leq 0.000 \mathrm{I}) \text {. Nonfatal recipients } \\
\text { versus fatal recipients: shorter length of hospital stay } \\
\text { (median: } 16 \text { days versus } 3 \mathrm{I} \text { days, respectively; } P=0.002) \text {. } \\
\text { Nonfatal recipients received peramivir sooner after their } \\
\text { disease onset than fatal recipients did. } \\
(7 \text { days versus } 9 \text { days; } P=0.02) \text {. }\end{array}$ & $\begin{array}{l}\text { Before receiving peramivir, peramivir } \\
\text { recipients were in a more serious condition } \\
\text { than untreated patients were. } \\
\text { Further study in randomized controlled } \\
\text { trials is needed. }\end{array}$ & Louie & 37 \\
\hline $\begin{array}{l}\text { Approximately I, } 274 \text { hospitalized patients } \\
\text { received peramivir. }\end{array}$ & $\begin{array}{l}\text { Peramivir treatments are available } \\
\text { for } \mathrm{pHINI} \text {-hospitalized patients. }\end{array}$ & Yu & 32 \\
\hline
\end{tabular}

because peramivir has a high rate of renal excretion. Death and renal failure were unlikely to have affected outcomes adversely because many patients were critically ill and had independent risk factors for flu-related complications. In view of the uncertainties related to the safety information reporting system, the authors were unable to estimate the incidence of AEs. ${ }^{38}$

\section{Pediatric patients}

Sugaya et al ${ }^{12}$ described 116 AEs in 73 (62.4\%) of the 117 patients with pH1N1 infection enrolled in the Phase III study described in the section "Dose-response study of children". The data showed that 107 AEs occurred in $67(62.6 \%)$ of the 107 patients who received a single dose; nine AEs occurred in six (60.0\%) of the ten patients who received two doses. Of 117 patients, 45 events in 34 patients (29.1\%) might have been related to the drug, and they were regarded as adverse drug reactions. Many AEs were mild or moderate. Most AEs were gastrointestinal disorders: diarrhea (16.2\%); vomiting (11\%); and a decrease in neutrophil count (21.4\%). Psychiatric disorders such as abnormal behavior were found in $2.6 \%$ of subjects (Table 1). ${ }^{12}$

Randolph et $\mathrm{al}^{39}$ reported the clinical characteristics of children with pH1N1 infection admitted to a PICU in the US; $2.5 \%$ of 838 children with $\mathrm{pH} 1 \mathrm{~N} 1$ admitted to the PICU received peramivir. Patients who received peramivir had already been regarded as having a high risk of death (relative risk: 6.0; range: 3.6-9.9). No severe AEs related to peramivir were reported. Children with pre-existing neurologic conditions and immune compromise were at increased risk of pH1N1-associated death after PICU admission. ${ }^{39}$ Most of the available safety data indicated that the single-dose use of peramivir in adults and pediatric outpatient populations commonly led to AEs that reportedly included diarrhea, nausea, vomiting, and neutropenia. ${ }^{12,61,62}$ Available data related to AEs of multiple-dose peramivir in critically ill patients are scarce. ${ }^{37}$

\section{Recommendations and difficulties of intravenous peramivir based on previous reports}

Peramivir-resistant virus

The two major classes of antivirals for the treatment and prevention of influenza are M2 inhibitors and NAIs. The M2 inhibitors amantadine and rimantadine, which only act on influenza A viruses, are not pertinent in clinical use against circulating seasonal H3N2 and (H1N1) pdm09. Moreover, all $\mathrm{H} 7 \mathrm{~N} 9$ and many $\mathrm{H} 5 \mathrm{~N} 1$ strains are resistant to the M2 inhibitors. ${ }^{63}$

An NAI binds to an influenza virus' NA, inhibiting the enzyme's activity. When NA proteins of viruses change, NAIs lose their ability to bind to and inhibit the function of the virus' NA. A particular genetic mutation of the NA prevents NAIs from inhibiting NA activity, thereby producing a resistant virus. ${ }^{64}$ Resistant viruses have been isolated from oseltamivir-treated adult patients and from natural environments with no apparent history of drug exposure. ${ }^{65}$ The H274Y mutation confers resistance to oseltamivir and peramivir, but not to zanamivir. Mutations at I222 and R292 can also reduce peramivir sensitivity. McKimm-Breschkin ${ }^{63}$ reviewed the details of viral mutations and their relative susceptibility to NAIs. In early studies ${ }^{66-71}$ in which the viruses were primarily seasonal H1N1 strains, oseltamivir-resistant H274Y mutant viruses were isolated from patients after treatment or prophylaxis with oseltamivir or peramivir, and also from untreated patients. During the winter of 2007-2008, an oseltamivir-resistant seasonal influenza A (H1N1) strain with an H274Y mutation emerged in the northern hemisphere ${ }^{72,73}$ and rapidly spread around the world. ${ }^{74-76}$ During the pandemic, a resistant $\mathrm{A} / \mathrm{H} 1 \mathrm{~N} 1$ virus (Russian strain) was displaced by the pH1N1 virus sensitive to NAIs. To date, oseltamivir resistance 
remains low among the circulating influenza viruses in the world. Approximately $0.5 \%-1.0 \%$ of community $\mathrm{pH} 1 \mathrm{~N} 1$ isolates are currently resistant to oseltamivir or peramivir. ${ }^{63}$ The $\mathrm{H} 275 \mathrm{Y}$ mutation in $\mathrm{pH} 1 \mathrm{~N} 1$ was associated with a high level of resistance to oseltamivir. It conferred an intermediate level of resistance to peramivir. ${ }^{77,78} \mathrm{~A}$ cluster of 14 cases of influenza $\mathrm{B}$ viruses with an $\mathrm{I} 222 \mathrm{~V}$ mutation conferring reduced susceptibility to both oseltamivir and peramivir has also been reported recently. ${ }^{79}$ In addition, the R292K mutation confers a very high level of resistance to oseltamivir, and intermediate resistance to peramivir. ${ }^{80}$ The $\mathrm{H} 275 \mathrm{Y}$ mutation was associated with a high level of resistance to oseltamivir. It conferred an intermediate level of resistance to peramivir. ${ }^{77,78}$

Takashita et a ${ }^{81}$ recently reported that six viruses possessed an $\mathrm{H} 275 \mathrm{Y}$ substitution in the NA protein, which conferred cross-resistance to oseltamivir and peramivir during November and December 2013. Furthermore, McKimm-Breschkin et al ${ }^{82}$ characterized human H1N1 influenza isolate $\mathrm{A} /$ Hokkaido/15/02, which had hemagglutinin and NA mutations that reduce drug susceptibility to oseltamivir, zanamivir, and peramivir. Two viruses had a NA Y155H mutation that reduced its susceptibility to all NAIs. One virus had both the $\mathrm{Y} 155 \mathrm{H}$ mutation and a hemagglutinin D225G mutation. The authors also isolated the third mutant virus, which had both NA V114I and hemagglutinin D225N mutations. This report is the first to describe a demonstration of a specific hemagglutinin mutation that is correlated with reduced drug susceptibility. ${ }^{82}$

Two patients became infected with a sensitive virus first, and subsequently became infected with a virus which was resistant to both osertamivir and peramivir but sensitive to zanamivir, probably because of rapid selection. ${ }^{77}$ Viral isolates collected from the patients on day 0 included the wild-type virus. The resistant viruses with a $\mathrm{H} 275 \mathrm{Y}$ mutation were isolated at 9 days and 14 days of therapy. All other isolates that were collected after those days included the resistant virus conferring H275Y. After the initial diagnosis was made, an enteral antiviral treatment including peramivir was administered to two patients with suspected viral replication that had been prolonged for 44 days in one patient and for 46 days in the other. Both patients experienced overall improvements in their symptoms. ${ }^{77}$ Reportedly, one effect of the continuous administration of intramuscular antiviral treatment was the reduction of the fatality rate for immunosuppressed mice infected with influenza A (H1N1) 2009 virus. $^{78}$ Once infected with the resistant virus, as described earlier in this section, monitoring of the resistant virus and research for a treatment strategy must be continued.

Antiviral treatments are widely used in many adults and children in Japan. Table 4 shows that higher levels of

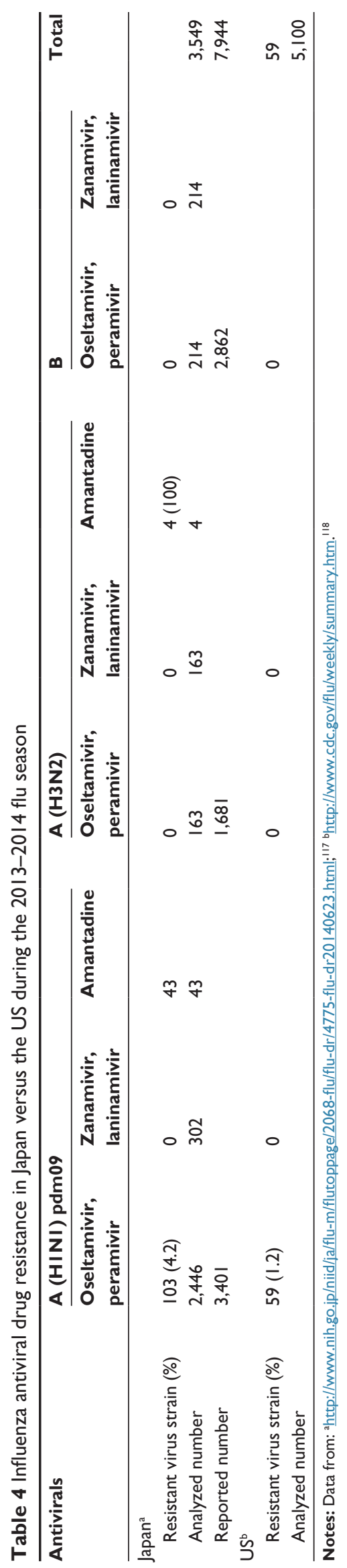


resistance to oseltamivir and peramivir in Japan are likely to be attributable to their heavier usage than in the US. Emergent resistance during treatment is still uncommon. Global surveillance must be continued.

\section{Avian influenza viruses}

Since November 2003, more than 600 sporadic cases of human infection with highly pathogenic avian influenza (HPAI) A (H5N1) virus have been reported, mainly in Asian countries and Egypt. ${ }^{83}$ Other subtypes of avian influenza A viruses have been reported: HPAI A (H7N3) virus in Mexico since June $2012 ;^{84}$ and variant influenza A (H3N2) viruses in the US since July $2011 .^{85}$ Since the first human case of reassortant avian-origin influenza A (H7N9) virus was reported in Shanghai, People's Republic of China in March 2013, ${ }^{86}$ more than 400 cases of human A (H7N9) virus infection have been reported through April 2014. ${ }^{87}$ Health officials worldwide are becoming increasingly alarmed about the influenza virus' resistance to NAIs.

During the $2009 \mathrm{H} 1 \mathrm{~N} 1$ pandemic, a reduction in disease severity by the early administration of NAIs was observed. ${ }^{88}$ In addition, the early administration of NAIs was effective against HPAIA (H5N1) infection in Egypt. ${ }^{89}$ Data related to human infections with seasonal, pandemic, and HPAIA (H5N1) viruses indicated that the earlier an antiviral treatment is initiated, the greater the clinical benefit. ${ }^{90}$ Little is known about the clinical effect of a NAI on A (H7N9) virus. However, in the laboratory, oseltamivir showed a reduction of mortality in A (H7N9)-infected mice, and administration within 48 hours from disease onset was more effective. ${ }^{91}$ According to a report of the clinical courses of 111 cases of A (H7N9) infection in the People's Republic of China, $97.3 \%$ of patients were administered peramivir or oseltamivir, but only $10 \%$ of them were administered within 48 hours from the onset of the infection. Therefore, the efficacy is unclear. Patients with A (H7N9) virus infection were highly complicated with respiratory failure and pneumonia. ${ }^{92}$ Considering these results, the CDC recommended early oral or enterical administration of oseltamivir for uncomplicated influenza, hospitalized patients, or severe or complicated cases because oseltamivir has been used widely to date. ${ }^{93}$ Early intravenous administration of peramivir has been recommended in the Japanese Interim Guidance for avian influenza A (H7N9) virus infections in humans. ${ }^{94}$ The optional administration of peramivir should be investigated in future studies.

The CDC guidance suggests a twofold (10-day) extended administration period of NAIs as an option in severe cases.
In uncomplicated cases with A (H7N9) virus infection, drug administration is suggested to last 5 days. ${ }^{95}$ The viral sequence data indicate susceptibility to NAIs, except for an R292K mutation in the NA protein of the A/Shanghai/1/2013 virus. ${ }^{90}$ In the People's Republic of China, oseltamivir treatment was unsuccessful in patients with A (H7N9) virus infection. Resistant virus conferring mutations in the NA gene was detected in patients with severe respiratory failure. ${ }^{96}$ The policy regarding NAI recommendation remains unchanged because few cases have been observed, but future studies must survey changes carefully.

\section{Treatment of peramivir}

Peramivir has been used at the dosage suggested by the CDC, as based on results from Phase II and Phase III trials conducted with the intravenous administration of single $300 \mathrm{mg}$ or $600 \mathrm{mg}$ doses of peramivir treatment, which showed statistically significant effects compared to placebo in adult patients with acute uncomplicated influenza. ${ }^{22,62}$ The standard adult dose of peramivir is $600 \mathrm{mg}$, which is administered intravenously once daily for 5-10 days. However, the single $300 \mathrm{mg}$ or $600 \mathrm{mg}$ dosage of intravenously administered peramivir might be an alternative to a 5-day oral dosage of oseltamivir for patients with uncomplicated seasonal influenza. ${ }^{11}$ A retrospective study that did not use randomized placebo-controlled trials showed that the clinical efficacy of peramivir was not inferior to that of oseltamivir. ${ }^{50}$

A Phase III trial of peramivir administered intravenously to hospitalized patients for $1-5$ days showed that the influenza illness duration was significantly shorter in the $600 \mathrm{mg}$ group than in the $300 \mathrm{mg}$ group. ${ }^{25}$ A large, open-label, randomized trial showed no significant clinical or virological difference between $300 \mathrm{mg}$ of peramivir administered intravenously twice daily and a $600 \mathrm{mg}$ dose administered once daily for 5 days. ${ }^{24}$ Other clinical trials show that the administration of peramivir at doses of $400 \mathrm{mg}$ or $200 \mathrm{mg}$ once daily and $300 \mathrm{mg}$ twice daily for 5 days are treatment options. ${ }^{24,26}$ In children, single doses of $10 \mathrm{mg} / \mathrm{kg}$ (600 mg maximum) of intravenously administered peramivir for 1 day is effective both clinically and virologically in an open-label, uncontrolled study. Despite the scarcity of safety and efficacy data (Table 3), intravenously administered peramivir appears to be effective for pediatric patients. ${ }^{48,49}$

A Policy Statement of The Japanese Association for Infectious Diseases ${ }^{97}$ recommends the early administration of intravenously administered peramivir for uncomplicated or hospitalized adult and pediatric patients, including those who are unable to receive inhaled or oral NAIs. Recom- 
mended doses for patients with impaired renal function are available. ${ }^{62,63}$

The 2013-2014 CDC guidance for the use of influenza antiviral drugs remains unchanged from last season because high susceptibility to oseltamivir and zanamivir during the 2012-2013 flu season continues. ${ }^{63,95}$

Resistant viruses have evoked concern in Japan, where NAIs are used most. Treatment of NAI-resistant virus-infected children has yielded poor results. Hosoya et al most highly recommended the once-daily administration of $10 \mathrm{mg} / \mathrm{kg}$ of peramivir for 5 consecutive days in the official website of Japan Pediatric Society. ${ }^{98}$ In a macaque model infected with HPAIA (H5N1), repeated peramivir administration $(30 \mathrm{mg} / \mathrm{kg} /$ day once a day for 5 days) starting immediately after infection significantly reduced viral titers in the upper respiratory tract $(P<0.05) .{ }^{99}$ These results provide supportive evidence for the repeated administration of peramivir to highly pathogenic avian influenza virus infection.

The 2013 Interim Guidance for humans infected with the avian influenza A (H7N9) virus is expected to be helpful for the use of antiviral drugs in the treatment of human infections with avian influenza A (H7N9). ${ }^{93}$ It is crucially important to administer an antiviral agent as soon as possible, even in uncomplicated patients. Higher doses with longer treatment regimens might be necessary in immunosuppressed persons, although the clinical benefit is unknown. ${ }^{93}$ Table 5 presents the peramivir treatment parameters based on the evidence presented earlier.

\section{Rapid diagnosis and early antiviral treatment}

Observational data from the $\mathrm{pH} 1 \mathrm{~N} 1$ pandemic suggest that there is an association of early antiviral treatment and increased survival, even for children, pregnant women, and severely ill patients. ${ }^{100-103}$

Influenza can be fatal in children, thereby underscoring the importance of recommending that all children receive antiviral treatment as early as possible. ${ }^{104}$ Therefore, the 2013-2014 guidance recommends early antiviral treatment by oseltamivir or zanamivir for any patient with confirmed or suspected influenza who is hospitalized; has severe, complicated, or progressive illness; or who is at higher risk of complications (age $<2$ years old or those with a medical condition). ${ }^{95}$

Peramivir, which is suitable for critically ill patients under 2 years of age, and for others who cannot receive oral antiviral treatment and who need only intravenous administration, is anticipated as a treatment option based on the favorable results of recent clinical trials..$^{24,26}$

Clinics and hospitals commonly use rapid diagnostic tests. Most people with an influenza-like illness in Japan are tested and treated with an appropriate choice of antiviral drugs if

Table 5 Recommendation of intravenous peramivir use for the treatment of influenza

\begin{tabular}{|c|c|c|c|}
\hline Subjects & Dosage & Duration & $\begin{array}{l}\text { Reference for guidance or underlying } \\
\text { data for recommendation }\end{array}$ \\
\hline \multicolumn{4}{|c|}{ Severe or complicated hospitalized, high-risk patients } \\
\hline \multirow[t]{5}{*}{ Adults ( $\geq 18$ years) } & Single $300 \mathrm{mg}$ or $600 \mathrm{mg}$ dose & $5-10$ days & Centers for Disease Control and Prevention \\
\hline & $\begin{array}{l}300 \text { mg twice daily or } 600 \text { mg } \\
\text { once daily }\end{array}$ & 5 days & Ison et $\mathrm{al}^{24}$ \\
\hline & $400 \mathrm{mg}$ or $200 \mathrm{mg}$ once daily & 5 days & Ison et $\mathrm{al}^{26}$ \\
\hline & $\begin{array}{l}300 \mathrm{mg} \text { or } 600 \mathrm{mg} \text { once daily } \\
(600 \mathrm{mg} \text { is better) }\end{array}$ & I-5 days & Kohno et al" \\
\hline & $300 \mathrm{mg}$ or $600 \mathrm{mg}$ once daily & $\mathrm{I}-5$ days & Kohno et $\mathrm{al}^{25}$ \\
\hline \multicolumn{4}{|l|}{ Uncomplicated adults } \\
\hline Adults & $300 \mathrm{mg}$ or $600 \mathrm{mg}$ & I day & Kohno et $\mathrm{al}^{\prime \prime}$ \\
\hline \multicolumn{4}{|l|}{ Children } \\
\hline Children & $(\mathrm{mg} / \mathrm{kg})$ & Initial treatment & Centers for Disease Control and Prevention \\
\hline Birth through 30 days & $6 \mathrm{mg} / \mathrm{kg}$ & courses of 5 days & \\
\hline 31 days through 90 days & $8 \mathrm{mg} / \mathrm{kg}$ & or 10 days are & \\
\hline 91 days through 180 days & $10 \mathrm{mg} / \mathrm{kg}$ & permitted & \\
\hline 181 days through 5 years & $12 \mathrm{mg} / \mathrm{kg}$ & & \\
\hline \multirow[t]{2}{*}{6 years through 17 years } & $10 \mathrm{mg} / \mathrm{kg}$ & & \\
\hline & The maximum daily dose is $600 \mathrm{mg}$ & & \\
\hline H7N9 pediatric patients & Higher-dose NAls; & NAls (for example, & Centers for Disease Control and Prevention ${ }^{92}$ \\
\hline Children $<5$ years, with highest & optimal dose is uncertain & I0 days of treatment) & Longer courses of treatment (for example, \\
\hline \multirow[t]{2}{*}{ risk for those aged $<2$ years old } & & optimal duration & I0 days of treatment) should be considered \\
\hline & & is uncertain & for severely ill hospitalized H7N9 patients \\
\hline Infected with NAI-resistant virus & Once daily 10 mg/kg & 5 days & Japan Pediatric Society ${ }^{98}$ \\
\hline
\end{tabular}

Abbreviation: NAl, neuraminidase inhibitor. 
test results are positive. ${ }^{105,106}$ Suspected flu cases ${ }^{107}$ are mostly diagnosed with influenza within 48 hours after the onset of illness. Then, prompt treatment with NAIs is initiated. Unfortunately, the rapid diagnostic test sensitivity is low. ${ }^{107}$

In the US, over one-third of cases during the past two seasons received no antiviral treatment. ${ }^{108}$ Lindegren and Schaffner ${ }^{109}$ reported that several elements are necessary for earlier antiviral treatment, including more effective studies of antivirals on meaningful clinical endpoints among those at highest risk, and more sensitive and specific rapid diagnostic tests. Treatment within 48 hours of illness onset was significantly associated with survival $(P=0.04)$. In cases where NAI treatment was initiated earlier in the course of the illness, these patients were less likely to die. ${ }^{110}$ The recent decreased frequency of NAI treatment for influenza might be placing untreated critically ill children at an increased risk of death. ${ }^{43}$ Early antiviral treatment in high-risk patients with influenza infection might significantly reduce secondary bacterial pneumonia, unnecessary antibiotic prescription, and health careassociated costs. Japan might have had the lowest case fatality rate $(<0.001 \% ; 198 / 20.7$ million $)$ in the $\mathrm{H} 1 \mathrm{~N} 1$ pandemic of 2009 , mainly because of the universal implementation of early treatment with NAI. ${ }^{111}$ The second main reason might be that early treatment was initiated for all patients nationwide using doctors' clinical judgment. A third reason might be that peramivir is not expensive in Japan because peramivir is a long-acting NAI, administered only on the first treatment day. ${ }^{111}$ The Japanese example highlights possibilities for the reduction of influenza mortality in other countries.

\section{Conclusion}

Peramivir, which is generally safe and well tolerated, can be effective in adult and pediatric patients with influenza infection. In recent years, the potential threat of influenza pandemics and the constant emergence of new antiinfluenza, drug-resistant influenza viruses have weakened the defensive role of the current anti-influenza drugs.

Antivirals, including peramivir, are still widely used in Japan after the pandemic. The clinical benefits of early antiviral treatment, the estimated cost effectiveness, and the effectiveness of antiviral drugs against mutant viruses must be acknowledged worldwide to minimize influenza-related mortality.

\section{Disclosure}

The authors report no conflicts of interest in this work.

\section{References}

1. Glezen WP. Clinical practice. Prevention and treatment of seasonal influenza. N Engl J Med. 2008;359(24):2579-2585.
2. Fiore AE, Fry A, Shay D, Gubareva L, Bresee JS, Uyeki TM; Centers for Disease Control and Prevention (CDC). Antiviral agents for the treatment and chemoprophylaxis of influenza - recommendations of the Advisory Committee on Immunization Practices (ACIP). MMWR Recomm Rep. 2011;60(1):1-24.

3. Bouvier NM, Palese P. The biology of influenza viruses. Vaccine. 2008;26:D49-D53.

4. Gubareva LV, Kaiser L, Hayden FG. Influenza virus neuraminidase inhibitors. Lancet. 2000;355(9206):827-835.

5. Bright RA, Medina MJ, Xu X. Incidence of adamantane resistance among influenza A (H3N2) viruses isolated worldwide from 1994 to 2005: a cause for concern. Lancet. 2005;366(9492):1175-1181.

6. Bantia S, Parker CD, Ananth SL, et al. Comparison of the anti-influenza virus activity of RWJ-270201 with those of oseltamivir and zanamivir. Antimicrob Agents Chemother. 2001;45(4):1162-1167.

7. Bantia S, Arnold CS, Parker CD, Upshaw R, Chand P. Anti-influenza virus activity of peramivir in mice with single intramuscular injection. Antiviral Res. 2006;69(1):39-45.

8. Bautista E, Chotpitayasunondh T, Gao Z, et al; Writing Committee of the WHO Consultation on Clinical Aspects of Pandemic (H1N1) 2009 Influenza. Clinical aspects of pandemic 2009 influenza A (H1N1) virus infection. N Engl J Med. 2010;362(18):1708-1719.

9. BioCryst Pharmaceuticals. [homepage on the Internet]. Birmingham:Corporate Partnerships Available from: http://www. biocryst.com/peramivir. Accessed September 4, 2014.

10. Fever lasting for less than 34 hours in patients treated with peramivir [pamphlet]. Osaka: Shionogi \& Co., Ltd.; 2013.

11. Kohno S, Yen MY, Cheong HJ, et al; S-021812 Clinical Study Group. Phase III randomized, double-blind study comparing single-dose intravenous peramivir with oral oseltamivir in patients with seasonal influenza virus infection. Antimicrob Agents Chemother. 2011;55(11):5267-5276.

12. Sugaya N, Kohno S, Ishibashi T, Wajima T, Takahashi T. Efficacy, safety, and pharmacokinetics of intravenous peramivir in children with 2009 pandemic H1N1 influenza A virus infection. Antimicrob Agents Chemother. 2012;56(1):369-377.

13. BioCryst Pharmaceuticals. [homepage on the Internet]. Birmingham: BioCryst's Partner Green Cross Receives Marketing \& Manufacturing Approval for Peramivir in South Korea. Available from: http://investor.shareholder.com/biocryst/releasedetail.cfm?ReleaseID=499386. Accessed September 4, 2014.

14. Birnkrant D, Cox E. The Emergency Use Authorization of peramivir for treatment of 2009 H1N1 influenza. N Engl J Med. 2009;361(23): 2204-2207.

15. Jefferson T, Jones MA, Doshi P, et al. Neuraminidase inhibitors for preventing and treating influenza in healthy adults and children. Cochrane Database Syst Rev. 2014;4:CD008965.

16. Drusano GL, Treanor J, Fowler C, et al. RWJ-270201 rapidly clears both influenza A and B in challenge studies. III International Symposium on Respiratory Viral Infections; December 1; 2000; St.Lucia.

17. Young D, Fowler C, Bush K. RWJ-270201 (BCX-1812): a novel neuraminidase inhibitor for influenza. Philos Trans $R$ Soc Lond B Biol Sci. 2001;356(1416):1905-1913.

18. Hayden FG, Treanor JJ, Qu R, Fowler C. Safety and efficacy of an oral neuraminidase inhibitor RWJ-270201 in treating experimental influenza A and B in healthy adult volunteers. Poster presented at: 40th Interscience Conference on Antimicrobial Agents and Chemotherapy; September 17-20, 2000; Toronto, Ontario. Abstract.

19. Sidwell RW, Smee DF. Peramivir (BCX-1812, RWJ-270201): potential new therapy for influenza. Expert Opin Investig Drugs. 2002;11(6): 859-869.

20. Barroso L, Treanor J, Gubareva L, Hayden FG. Efficacy and tolerability of the oral neuraminidase inhibitor peramivir in experimental human influenza: randomized, controlled trials for prophylaxis and treatment. Antivir Ther. 2005;10(8):901-910.

21. Castillo R, Holland LE, Boltz DA. Peramivir and its use in H1N1 influenza. Drugs Today (Barc). 2010;46(6):399-408.

22. Shetty AK, Peek LA. Peramivir for the treatment of influenza. Expert Rev Anti Infect Ther. 2012;10(2):123-143. 
23. Kohno S, Kida H, Mizuguchi M, Shimada J; S-021812 Clinical Study Group. Efficacy and safety of intravenous peramivir for treatment of seasonal influenza virus infection. Antimicrob Agents Chemother. 2010;54(11):4568-4574.

24. Ison MG, Fraiz J, Heller B, et al. Intravenous peramivir for treatment of influenza in hospitalized patients. Antivir Ther. Epub August 28, 2013.

25. Kohno S, Kida H, Mizuguchi M, et al; S-021812 Clinical Study Group. Intravenous peramivir for treatment of influenza A and B virus infection in high-risk patients. Antimicrob Agents Chemother. 2011;55(6):2803-2812.

26. Ison MG, Hui DS, Clezy K, et al. A clinical trial of intravenous peramivir compared with oral oseltamivir for the treatment of seasonal influenza in hospitalized adults. Antivir Ther. 2013;18(5):651-661.

27. Bennett $R$ [webpage on the Internet]. BioCryst announces outcome from the peramivir Phase 3 interim analysis. Durham, NC: BioCryst Pharmaceuticals, Inc.; 2012. Available from: http://investor.shareholder.com/biocryst/ releasedetail.cfm?ReleaseID=719562. Accessed November 7, 2012.

28. Smith SM, Gums JG. Antivirals for influenza: strategies for use in pediatrics. Paediatr Drugs. 2010;12(5):285-299.

29. Mancuso CE, Gabay MP, Steinke LM, Vanosdol SJ. Peramivir: an intravenous neuraminidase inhibitor for the treatment of 2009 H1N1 influenza. Ann Pharmacother. 2010;44(7-8):1240-1249.

30. Centers for Disease Control and Prevention. [homepage on the Internet]. Atlanta: Updated Interim Recommendations for the Use of Antiviral Medications in the Treatment and Prevention of Influenza for the 2009-2010 Season [updated 2009 December 7] Available from: http:// www.cdc.gov/h1n1flu/recommendations.htm. Accessed September 4, 2014.

31. Shrestha SS, Swerdlow DL, Borse RH, et al. Estimating the burden of 2009 pandemic influenza A (H1N1) in the United States (Apr 2009-Apr 2010). Clin Infect Dis. 2011;52 Suppl 1:S75-S82.

32. Yu Y, Garg S, Yu PA, et al. Peramivir use for treatment of hospitalized patients with influenza A(H1N1)pdm09 under emergency use authorization, Oct 2009-Jun 2010. Clin Infect Dis. 2012;55(1):8-15.

33. Doshi S, Kamimoto L, Finelli L, et al. Description of antiviral treatment among adults hospitalized with influenza before and during the 2009 pandemic: United States, 2005-2009. J Infect Dis. 2011;204(12): $1848-1856$

34. Fry AM, Pérez A, Finelli L. Use of intravenous neuraminidase inhibitors during the 2009 pandemic: results from population-based surveillance. JAMA. 2011;306(2):160-162.

35. Hernandez JE, Adiga R, Armstrong R, et al; eIND Peramivir Investigators. Clinical experience in adults and children treated with intravenous peramivir for 2009 influenza A (H1N1) under an Emergency IND program in the United States. Clin Infect Dis. 2011;52(6):695-706.

36. Jain S, Fry AM. Peramivir: another tool for influenza treatment? Clin Infect Dis. 2011;52(6):707-709.

37. Louie JK, Yang S, Yen C, Acosta M, Schechter R, Uyeki TM. Use of intravenous peramivir for treatment of severe influenza A(H1N1)pdm09. PLoS One. 2012;7(6):e40261.

38. Sorbello A, Jones SC, Carter W, et al. Emergency use authorization for intravenous peramivir: evaluation of safety in the treatment of hospitalized patients infected with $2009 \mathrm{H} 1 \mathrm{N1}$ influenza A virus. Clin Infect Dis. 2012;55(1):1-7.

39. Randolph AG, Vaughn F, Sullivan R, et al; Pediatric Acute Lung Injury and Sepsis Investigator's Network and the National Heart, Lung, and Blood Institute ARDS Clinical Trials Network. Critically ill children during the 2009-2010 influenza pandemic in the United States. Pediatrics. 2011;128(6):e1450-e1458.

40. Jouvet P, Hutchison J, Pinto R, et al. Critical illness in children with influenza A/pH1N1 2009 infection in Canada. Pediatr Crit Care Med. 2010;11(5):603-609.

41. The ANZIC Influenza Investigators. Critical care services and 2009 H1N1 influenza in Australia and New Zealand. N Engl J Med. 2009; 361(20):1925-1934

42. Farias JA, Fernandez A, Monteverde E, et al. Critically ill infants and children with influenza A (H1N1) in pediatric intensive care units in Argentina. Intensive Care Med. 2010;36(6):1015-1022.
43. Louie JK, Yang S, Samuel MC, Uyeki TM, Schechter R. Neuraminidase inhibitors for critically ill children with influenza. Pediatrics. 2013; 132(6):e1539-e1545.

44. Treanor JJ, Hayden FG, Vrooman PS, et al. Efficacy and safety of the oral neuraminidase inhibitor oseltamivir in treating acute influenza: a randomized controlled trial. US Oral Neuraminidase Study Group. JAMA. 2000;283(8):1016-1024.

45. Urushihara H, Matsui S, Kawakami K. Emergency authorization of medical products: regulatory challenges from the $2009 \mathrm{H} 1 \mathrm{~N} 1$ influenza pandemic in Japan. Biosecur Bioterror. 2012;10(4):372-382.

46. Tominaga T, Ando Y, Nagai N, Sato J, Kondo T. Balancing societal needs and regulatory certainty: the case study of peramivir in Japan. Clin Pharmacol Ther. 2013;93(4):342-344.

47. Takemoto Y, Asai T, Ikezoe I, et al. Clinical Effects of Oseltamivir, Zanamivir, Laninamivir and Peramivir on Seasonal Influenza Infection in Outpatients in Japan during the Winter of 2012-2013. Chemotherapy. 2013;59(5):373-378

48. Shobugawa Y, Saito R, Sato I, et al. Clinical effectiveness of neuraminidase inhibitors - oseltamivir, zanamivir, laninamivir, and peramivir for treatment of influenza $\mathrm{A}(\mathrm{H} 3 \mathrm{~N} 2)$ and $\mathrm{A}(\mathrm{H} 1 \mathrm{~N} 1) \mathrm{pdm} 09$ infection: an observational study in the 2010-2011 influenza season in Japan. $J$ Infect Chemother. 2012;18(6):858-864.

49. Hikita T, Hikita H, Hikita F, Hikita N, Hikita S. Clinical effectiveness of peramivir in comparison with other neuraminidase inhibitors in pediatric influenza patients. Int J Pediatr. 2012;2012:834181.

50. Yoshino Y, Seo K, Koga I, Kitazawa T, Ota Y. Clinical efficacy of peramivir in adult patients with seasonal influenza during the winter of 2012 in Japan. Clin Respir J. Epub March 10, 2014.

51. Donner B, Bader-Weder S, Schwarz R, Peng MM, Smith JR, Niranjan V. Safety profile of oseltamivir during the 2009 influenza pandemic. Pharmacoepidemiol Drug Saf. 2011;20(5):532-543.

52. Michiels B, Van Puyenbroeck K, Verhoeven V, Vermeire E, Coenen S. The value of neuraminidase inhibitors for the prevention and treatment of seasonal influenza: a systematic review of systematic reviews. PLoS One. 2013;8(4):e60348.

53. Burch J, Paulden M, Conti S, et al. Antiviral drugs for the treatment of influenza: a systematic review and economic evaluation. Health Technol Assess. 2009;13(58): 1-265, iii-iv.

54. Relenza dear doctor letter in EU follows US advisory. In: "The Pink Sheet" F-D-C Reports. Chevy Chase, MD: 2000.

55. Williamson JC, Pegram PS. Respiratory distress associated with zanamivir. N Engl J Med. 2000;342(9):661-662.

56. Wang K, Shun-Shin M, Gill P, et al. Neuraminidase inhibitors for preventing and treating influenza in children. Cochrane Database Syst Rev. 2012;1:CD002744.

57. Okumura A, Kubota T, Kato T, Morishima T. Oseltamivir and delirious behavior in children with influenza. Pediatr Infect Dis J. 2006;25(6):572.

58. Toovey S, Rayner C, Prinssen E, et al. Assessment of neuropsychiatric adverse events in influenza patients treated with oseltamivir: a comprehensive review. Drug Saf. 2008;31(12):1097-1114.

59. Hama R. Oseltamivir's adverse reactions: fifty sudden deaths may be related to central suppression. BMJ. 2007;335(7610):59.

60. TAMIFLU ${ }^{\circledR}$ (oseltamivir phosphate) [prescribing information]. South San Francisco, CA: Genentech, Inc.; 2012. Available from: http://www. accessdata.fda.gov/drugsatfda_docs/label/2011/021087s057lbl.pdf. Accessed September 4, 2014.

61. Shin JH, Kim BY, Park HR, Kim SW, Kim SW. The effect of pneumococcal polysaccharide vaccine in a mouse model of allergic rhinitis. Otolaryngol Head Neck Surg. 2013;148(3):383-390.

62. United States Food and Drug Administration. Emergency Use Authorization of Peramivir IV Fact Sheet for Health Care Providers. White Oak, MD: United States Food and Drug Administration; 2009. Available from: Available from: http://www.fda.gov/downloads/Drugs/ DrugSafety/PostmarketDrugSafetyInormationforPatientsandProviders/ UCM187811.pdf.

63. McKimm-Breschkin JL. Influenza neuraminidase inhibitors: antiviral action and mechanisms of resistance. Influenza Other Respir Viruses. 2013;7 Suppl 1:25-36. 
64. Centers for Disease Control and Prevention [webpage on the Internet]. Influenza antiviral drug resistance: questions and answers. Atlanta, GA; 2014. Available from: http://www.cdc.gov/flu/about/qa/ antiviralresistance.htm. Accessed February 28, 2014.

65. Gubareva LV, Webster RG, Hayden FG. Comparison of the activities of zanamivir, oseltamivir, and RWJ-270201 against clinical isolates of influenza virus and neuraminidase inhibitor-resistant variants. Antimicrob Agents Chemother. 2001;45(12):3403-3408.

66. Gubareva LV, Kaiser L, Matrosovich MN, et al. Selection of influenza virus mutants in experimentally infected volunteers treated with oseltamivir. J Infect Dis. 2001;183(4):523-31.

67. Kiso M, Mitamura K, Sakai-Tagawa Y, et al. Resistant influenza A viruses in children treated with oseltamivir: descriptive study. Lancet. 2004;364(9436):759-65.

68. Ward P, Small I, Smith J, et al. Oseltamivir (Tamiflu) and its potential for use in the event of an influenza pandemic. JAntimicrob Chemother. 2005;55(Suppl. 1):i5-21.

69. Stephenson I, Democratis J, Lackenby A, et al. Neuraminidase inhibitor resistance after oseltamivir treatment of acute influenza A and B in children. Clin Infect Dis. 2009;48(4):389-96.

70. Weinstock DM, Gubareva LV, Zuccotti G. Prolonged shedding of multidrug-resistant influenza $A$ virus in an immunocompromised patient. New Engl J. 2003;348(9):867-8.

71. Renaud C, Kuypers J, Englund JA. Emerging oseltamivir resistance in seasonal and pandemic influenza A/H1N1. J Clin Virol. 2011;52(2): 70-78.

72. Ujike M, Shimabukuro K, Mochizuki K, Obuchi M, Kageyama T, Shirakura M, et al. Oseltamivir-resistant influenza viruses A (H1N1) during 2007-2009 influenza seasons, Japan. Emerg Infect Dis. 2010;16 (6):926-35.

73. Hauge SH, Dudman S, Borgen K, Lackenby A, Hungnes O. Oseltamivirresistant influenza viruses A (H1N1), Norway, 2007-08. Emerg Infect Dis. 2009; 15 (2):155-62.

74. Esposito S, Molteni CG, Daleno C, et al. Clinical importance and impact on the households of oseltamivir-resistant seasonal A/H1N1 influenza virus in healthy children in Italy. Virol J. 2010;7:202.

75. Casalegno JS, Bouscambert-Duchamp M, Caro V, et al. Oseltamivirresistant influenza A(H1N1) viruses in south of France, 2007/2009. Antivir Res. 2010;87(2):242-8.

76. Dharan NJ, Gubareva LV, Meyer JJ, et al. Infections with oseltamivirresistant influenza $\mathrm{A}(\mathrm{H} 1 \mathrm{~N} 1)$ virus in the United States. JAMA. 2009; 301(10):1034-41.

77. Memoli MJ, Hrabal RJ, Hassantoufighi A, Eichelberger MC, Taubenberger JK. Rapid selection of oseltamivir- and peramivir-resistant pandemic H1N1 virus during therapy in 2 immunocompromised hosts. Clin Infect Dis. 2010;50(9):1252-1255.

78. Abed Y, Boivin G, Yoshida R, Kodama M, Hernandez JE. Parenteral peramivir treatment for oseltamivir-resistant 2009 pandemic influenza A H1N1 viruses. J Infect Dis. 2011;204(10):1641-1642; author's reply 1642-1643.

79. Sleeman K, Sheu TG, Moore Z, et al. Influenza B viruses with mutation in the neuraminidase active site, North Carolina, USA, 2010-2011. Emerg Infect Dis. 2011;17(11):2043-2046.

80. Yen HL, McKimm-Breschkin JL, Choy KT, et al. Resistance to neuraminidase inhibitors conferred by an R292K mutation in a human influenza virus $\mathrm{H} 7 \mathrm{~N} 9$ isolate can be masked by a mixed $\mathrm{R} / \mathrm{K}$ viral population. MBio. 2013;4(4). pii: e00396-13.

81. Takashita E, Ejima M, Itoh R, et al. A community cluster of influenza A(H1N1)pdm09 virus exhibiting cross-resistance to oseltamivir and peramivir in Japan, Nov to Dec 2013. Euro Surveill. 2014;19(1). pii: 20666.

82. McKimm-Breschkin JL, Williams J, Barrett S, et al. Reduced susceptibility to all neuraminidase inhibitors of influenza H1N1 viruses with haemagglutinin mutations and mutations in non-conserved residues of the neuraminidase. J Antimicrob Chemother. 2013;68(10): 2210-2221.

83. Centers for Disease Control and Prevention [webpage on the Internet]. Highly pathogenic avian influenza A (H5N1) virus. Atlanta, GA: Centers for Disease Control and Prevention; 2014. Available from: http://www. cdc.gov/flu/avianflu/h5n1-virus.htm. Accessed February 27, 2014.
84. Lopez-Martinez I, Balish A, Barrera-Badillo G, et al. Highly pathogenic avian influenza $\mathrm{A}(\mathrm{H} 7 \mathrm{~N} 3)$ virus in poultry workers, Mexico, 2012. Emerg Infect Dis. 2013;19(9):1531-1534.

85. Centers for Disease Control and Prevention [webpage on the Internet]. Influenza A (H3N2) variant virus. Atlanta, GA: Centers for Disease Control and Prevention; 2013. Available from: http://www.cdc.gov/ $\mathrm{flu} / \mathrm{swineflu} / \mathrm{h} 3 \mathrm{n} 2 \mathrm{v}$-cases.htm. Accessed September 4, 2014.

86. Gao R, Cao B, Hu Y, et al. Human infection with a novel avian-origin influenza A (H7N9) virus. N Engl J Med. 2013;368(20):1888-1897.

87. World Health Organization. Confirmed Human Cases of Avian Influenza A(H7N9) Reported to WHO. Report 17 Data in WHO/HQ as of 08 April 2014, 17:00 GMT+1. Geneva, Switzerland: World Health Organization; 2014. Available from: http://www.who.int/influenza/human_animal interface/influenza_h7n9/17_ReportWebH7N9Number_20140408. pdf?ua=1. Accessed January 31, 2014.

88. Muthuri SG, Myles PR, Venkatesan S, Leonardi-Bee J, Nguyen-VanTam JS. Impact of neuraminidase inhibitor treatment on outcomes of public health importance during the 2009-2010 influenza A(H1N1) pandemic: a systematic review and meta-analysis in hospitalized patients. J Infect Dis. 2013;207(4):553-563.

89. Nagai Y. A watershed in clinical outcomes of human infections with highly pathogenic $\mathrm{H} 5 \mathrm{~N} 1$ avian influenza viruses: lessons from casemanagement in Egypt. Rev Med Virol. 2012;22(6):351-353.

90. Uyeki TM, Cox NJ. Global concerns regarding novel influenza A (H7N9) virus infections. N Engl J Med. 2013;368(20):1862-1864.

91. Baranovich T, Burnham AJ, Marathe BM, et al. The neuraminidase inhibitor oseltamivir is effective against A/Anhui/1/2013 (H7N9) influenza virus in a mouse model of acute respiratory distress syndrome. J Infect Dis. 2014;209(9):1343-1353.

92. Gao HN, Lu HZ, Cao B, et al. Clinical findings in 111 cases of influenza A (H7N9) virus infection. $N$ Engl J Med. 2013;368(24):2277-2285.

93. Centers for Disease Control and Prevention [webpage on the Internet]. Interim guidance on the use of antiviral agents for the treatment of human infections with avian influenza A (H7N9) virus. Atlanta, GA: Centers for Disease Control and Prevention; 2013. Available from: http://www.cdc.gov/flu/avianflu/h7n9-antiviral-treatment.htm. Accessed September 30, 2013.

94. The Japanese Association for Infectious Diseases [webpage on the Internet]. Interim guidance - avian influenza $\mathrm{A}(\mathrm{H} 7 \mathrm{~N} 9)$ virus infections in humans. Tokyo, Japan: The Japanese Association for Infectious Diseases; 2013. Available from: http://www.kansensho.or.jp/ influenza/1305_teigen.html. Accessed May 17, 2013. Japanese.

95. Centers for Disease Control and Prevention [webpage on the Internet]. Influenza antiviral medications: summary for clinicians (current for the 2013-2014 influenza season). Atlanta, GA: Centers for Disease Control and Prevention; 2013. Available from: http://www.cdc.gov/flu/professionals/antivirals/summary-clinicians.htm. Accessed March 21, 2014.

96. Hu Y, Lu S, Song Z, et al. Association between adverse clinical outcome in human disease caused by novel influenza A H7N9 virus and sustained viral shedding and emergence of antiviral resistance. Lancet. 2013;381(9885):2273-2279.

97. The Japanese Association for Infectious Diseases [webpage on the Internet]. The Japanese Association for Infectious Diseases policy statement: recommendations for influenza antiviral treatment (revised). Tokyo, Japan; 2011. Available from: http://www.kansensho.or.jp/influenza/110301soiv_teigen. html\#n02. Accessed May 1, 2011. Japanese.

98. Hosoya M. [homepage on the Internet]. Available from : Administration of peramivir against severe influenza cases. http://www.jpeds or.jp/uploads/files/2013_2014_influenza_3.pdf. Accessed January 27, 2014.

99. Kitano M, Itoh Y, Ishigaki H, et al. Efficacy of repeated intravenous administration of peramivir against highly pathogenic avian influenza A (H5N1) virus in cynomolgus macaques. Antimicrob Agents Chemother. 2014;58(8):4795-4803.

100. Jain S, Kamimoto L, Bramley AM, et al; 2009 Pandemic influenza A (H1N1) Virus Hospitalizations Investigation Team. Hospitalized patients with 2009 H1N1 influenza in the United States, Apr-Jun 2009. N Engl J Med. 2009;361(20):1935-1944. 
101. Farias JA, Fernández A, Monteverde E, et al. Critically ill infants and children with influenza A (H1N1) in pediatric intensive care units in Argentina. Intensive Care Med. 2010;36(6):1015-1022.

102. Dawood FS, Jain S, Finelli L, et al; Novel Swine-Origin Influenza A (H1N1) Virus Investigation Team. Emergence of a novel swine-origin influenza A (H1N1) virus in humans. N Engl J Med. 2009;360(25): 2605-2615.

103. Yu H, Liao Q, Yuan Y, et al. Effectiveness of oseltamivir on disease progression and viral RNA shedding in patients with mild pandemic 2009 influenza A H1N1: opportunistic retrospective study of medical charts in China. BMJ. 2010;341:c4779.

104. Wong KK, Jain S, Blanton L, et al. Influenza-associated pediatric deaths in the United States, 2004-2012. Pediatrics. 2013;132(5):796-804.

105. Sugaya N, Tamura D, Yamazaki M, et al. Comparison of the clinical effectiveness of oseltamivir and zanamivir against influenza virus infection in children. Clin Infect Dis. 2008;47(3):339-345.

106. Sugaya N, Shinjoh M, Mitamura K, Takahashi T. Very low pandemic influenza A (H1N1) 2009 mortality associated with early neuraminidase inhibitor treatment in Japan: analysis of 1000 hospitalized children. J Infect. 2011;63(4):288-294.

107. Uyeki TM, Prasad R, Vukotich C, et al. Low sensitivity of rapid diagnostic test for influenza. Clin Infect Dis. 2009;48(9):e89-e92.

108. Biggerstaff $M$, Jhung $M$, Reed C, et al. Influenza-like illness, the time to seek health-care, and influenza antiviral receipt during the 2010-2011 influenza season-United States. J Infect Dis. 2014;210(4):535-544.

109. Lindegren ML, Schaffner W. Treatment with neuraminidase inhibitors for high-risk patients with influenza: why is adherence to antiviral treatment recommendations so low? J Infect Dis. Epub April 13, 2014.

110. Dominguez-Cherit G, Lapinsky SE, Macias AE et al. Critically Ill patients with 2009 influenza A(H1N1) in Mexico. JAMA. 2009;302(17): 1880-1887.

111. Sugaya N. Widespread use of neuraminidase inhibitors in Japan. $J$ Infect Chemother. 2011;17(5):595-601.
112. Beigel J, Harman LA, Collis PJ, et al. Pharmacokinetic and Safety Evaluations of Escalating Doses of Peramivir Administered Intravenously in Healthy Volunteers. Presented at: 47th Interscience Conference on Antimicrobial Agents and Chemotherapy (ICAAC); September 17-20; 2007; Chicago, IL. Abstract A-1408.

113. Collis PJ, Harman LA, Kilpatrick JM, et al. A Placebo-Controlled Evaluation of the Safety and Pharmacokinetics of Multiple-Dose Intravenous Administration of Peramivir to Healthy Elderly Subjects. Presented at: 47th Interscience Conference on Antimicrobial Agents and Chemotherapy (ICAAC); September 17-20; 2007; Chicago, IL. Abstract A-1409.

114. Alexander WJ, Harman LA, Collis PJ, et al. Nasal and Pharyngeal Concentrations of Peramivir Following Intramuscular and Intravenous Administration in Healthy Volunteers. Presented at: 47th Interscience Conference on Antimicrobial Agents and Chemotherapy (ICAAC); September 17-20; 2007; Chicago, IL. Abstract A-1410.

115. BioCryst Pharmaceuticals. Evaluation of the Efficacy and Safety of Peramivir in Subjects With Uncomplicated Acute Influenza. Available from: http://clinicaltrials.gov/ct2/show/NCT00419263?term=NCT00 419263\&rank=1\#wrapper. NLM identifier: NCT00419263. Accessed September 22, 2014.

116. Atiee G, Tellier G, Collis P, et al. Virologic Analysis of Influenza Viruses after Therapy with a Single Intramuscular (IM) Dose of the Neuraminidase Inhibitor (NAI) Peramivir (PVR) Versus Placebo (PBO) in Patients with Influenza in the Outpatient (OP) Setting. Presented at: 49th Annual Meeting of the Infectious Diseases Society of America; October 20-23; 2011; Boston, MA. Abstract 1185.

117. nih.go.jp [homepage on the Internet]. Tokyo: National Institute of Infectious Diseases; 2014 [updated June 23, 2014]. http:/www.nih. go.jp/niid/ja/flu-m/flutoppage/2068-flu/flu-dr/4775-flu-dr20140623. html? Accessed June 23, 2014. Japanese.

118. Centers for Disease Control and Prevention [homepage on the Internet]. Atlanta, GA: Situation Update: Summary of Weekly FluView; 2014 [updated October 10, 2014]. Available from: http://www.cdc.gov/flu/ weekly/summary.htm. Accessed October 14, 2014.
Drug Design, Development and Therapy

\section{Publish your work in this journal}

Drug Design, Development and Therapy is an international, peerreviewed open-access journal that spans the spectrum of drug design and development through to clinical applications. Clinical outcomes, patient safety, and programs for the development and effective, safe, and sustained use of medicines are a feature of the journal, which

\section{Dovepress}

has also been accepted for indexing on PubMed Central. The manuscript management system is completely online and includes a very quick and fair peer-review system, which is all easy to use. Visit $\mathrm{http}: / /$ www.dovepress.com/testimonials.php to read real quotes from published authors. 